\title{
Descrying the bourgeoisie Sugar, capital and state in the Netherlands Indies, circa 1840-1884
}

Any attempt to descry the existence of a significant colonial bourgeoisie in Java during the middle decades of the nineteenth century might appear futile. ${ }^{1}$ An old, and apparently still lingering, orthodoxy postulates a colonial state uniquely in thrall to a powerful bureaucracy: one that exercised so extensive a control over resources as to largely preclude bourgeois capital formation. On this reading, colonial proprietorship, notably in sugar, was seignorial in nature rather than bourgeois. So much so that when, in the mid-1880s, a global commercial crisis threatened to strike down the industry, it had to be rescued from near-terminal obsolescence by Dutch metropolitan capital. I maintain that any such scenario is seriously misleading. Far from precluding the emergence of an Indisch, or Indies bourgeoisie, mid-century state intervention in the economy (in the form of the Cultuurstelsel or System of (State) Cultivations) proved to be its incubator. In conjunction, state contracts for the manufacture of sugar, mercantile activity, and colonial-metropolitan links formed the basis for bourgeois capital formation that underpinned, from the 1850s onward, a globally significant industrial project in sugar that was essential to the industry's late nineteenth-century evolution. In turn, these several developments have implications for a reappraisal of our

1 I am grateful to the University of Adelaide for providing financial support for the preparation and writing of this paper, and to friends in The Hague, Amsterdam and London, without whose kind hospitality my periods of research in Holland and the United Kingdom would have been impossible. I am especially indebted to Ulbe Bosma of the Internationaal Instituut voor Sociale Geschiedenis, Amsterdam, for ongoing discussion about the issues raised here and for his longterm encouragement and intellectual collaboration. Cees Fasseur, formerly of the Rijksuniversiteit Leiden, also deserves special mention, as a source of inspiration and encouragement, over many years, for a grateful foreign scholar delving into the intricacies of the Dutch and their 'Indies'. I am also indebted to two anonymous reviewers for their comments on an earlier draft of this paper.

G. ROGER KNIGHT is Associate Professor in the School of History and Politics at the University of Adelaide. He specializes in the social, economic and cultural dimensions of the Javanese sugar industry. His recent publications include: 'A precocious appetite; Industrial agriculture and the fertiliser revolution in Java's colonial cane fields, c. 1880-1914', Journal of Southeast Asian Studies, 37, 2006, pp. 43-64, and 'Sugar and servility; Themes of forced labour, resistance and accommodation in mid-nineteenth century Java', in: Edward Alpers, Gwyn Campbell and Michael Salman (eds), Resisting bondage in Indian Ocean, Africa and Asia, pp. 69-81, London/New York: Routledge, 2006. Dr Knight may be contacted at: roger.knight@adelaide.edu.au. 
understanding of the role of specifically metropolitan capital in the shaping of developments in the second half of the nineteenth century.

Around the beginning of the nineteenth century, the Verenigde OostIndische Compagnie's (VOC, Dutch East India Company) two-hundred-year monopoly control in Java and the other Dutch settlements in the area of present-day Indonesia fell into abeyance, with potentially far-reaching consequences for the development of colonial economy and society. In the 1910s, considerable tracts of land (notably in West Java but also many in East Java) were alienated by the Company's successor regimes to colonial European and Indies-Chinese interests. At about the same time, particularly though not exclusively in the Principalities of Central Java, a significant number of colonial entrepreneurs emerged, engaged chiefly in the production of commodities such as coffee and, to a lesser extent, indigo and sugar. For a variety of reasons, however, both they and the owners of the newly created estates failed to prosper. In the Principalities, official Dutch hostility and the Java War (1825-1830) temporarily interrupted the emergence of a European planter class. Elsewhere in the colony, neither estates nor planters made much headway in the production of commodities. ${ }^{2}$

Partly as a result of this, in 1830 the Netherlands Indies government established the Cultuurstelsel, which was to dominate the colonial economy of Java for the next fifty years (though formally abolished in the case of sugar around 1870, it took another decade or more to wind down). The Indies government itself took the lead in organizing and expanding export production, which took place under the supervision of the state and its officials, and on the basis of a forced requisition of peasant land and labour at the state's behest. In tandem, a state-linked corporation, the Nederlandsche Handel-Maatschappij (NHM, Netherlands Trading Corporation), was accorded prime responsibility for the marketing of the commodities produced under the Cultuurstelsel: primarily coffee, sugar and (initially) indigo. The NHM, founded in the Netherlands under royal patronage in 1824 - in an attempt to wrest the Java trade from the hands of the British - after 1830 became one of the mainstays of the Cultuurstelsel, initially even acting as banker to the Indies government. ${ }^{3}$ Based in Amsterdam, it was represented in the Indies by its Batavia branch office, universally known as the Factorij. To some, at least, the presence of the corporation as a further arm of the Indies government serves only to confirm the ubiquity of the state in mid-nineteenth-century Java. Only in the quasiautonomous Principalities, outside the purview of the Cultuurstelsel (which

2 On the entrepreneurs and landowners of this period, see Van Enk 1999; G. Roger Knight 1980; Bosma and Raben 2003; Houben 1994.

3 The standard work on the NHM remains Mansvelt 1924. The 'Birdseye View of the History' [in Dutch] in the preamble to the recent (new) inventory of the massive NHM Archive in the Nationaal Archief (National Archives), The Hague, provides a much-needed introduction to the firm, and is accompanied by a bibliography of relevant publications. See Wimmer and Tempelaars 1998. 
was confined to the directly administered 'government lands' - mostly in East Java, the north coast, and the far west of the colony), did the survivors of the preceding era of production continue to hold their own and begin to flourish.

This failure of a colonial bourgeoisie to establish itself in mid-nineteenthcentury Java on the basis of ownership of land and/or control over labour, meant that capital formation took place there in a different context, and on different lines, than that found in many other contemporary 'sugar colonies'. Westward across the Indian Ocean in Mauritius, the mid-century location of a technologically precocious industry that for a while matched or outpaced that of Java, the formation of domestic capital in sugar took place around the nucleus of land holding, of slave ownership, and (subsequently) of indenture. To the north, in the Philippines, where a burgeoning sugar industry existed on the island of Negros from the mid-century onward (and, during the same period, an older industry on Luzon was reinvigorated), land holding was again at the base of capital formation. In Cuba, Java's occidental coeval and at mid-century the largest sugar exporter in the world, the ownership of slaves - as well as of land - remained, until late in the century, the nucleus of bourgeois capital. ${ }^{4}$

Java was different: in the 'government lands' of North and East Java where the bulk of mid-nineteenth-century sugar production took place, neither land ownership nor direct control over labour constituted the main foundation for capital formation. This was partly because the state laid claim to ownership of the land and was reluctant to alienate it. Nor was it prepared to sanction the direct expropriation of the island's petty landholders in favour of a class of colonial sugar planters. In consequence, the nucleus around which colonial sugar capital began to form, from 1840 onward, was not the possession of land or of servile labour. Instead, it revolved around the possession of sugar factories and - above all - of state contracts for the manufacture of sugar issued in association with the Cultuurstelsel.

This close and long-term involvement of the Indies state in the expansion of sugar production and the formation of capital implied by the system of contracts, and the trade in sugar that it generated, had a profound impact on the historiography of the era. An older orthodoxy, still apparently deeply entrenched though not unchallenged, maintains that under the Cultuurstelsel Java evolved into a kind of bureaucratic polity avant la lettre, in which the state and its officials virtually monopolized access to resources. ${ }^{5}$ Bourgeois impulses

4 For Mauritius, see Allen 1999. For the Philippines, see, for example, Larkin 1993; McCoy 1982; Aguilar 1998; Billig 1994. On Cuba, see, for example, Bergad 1990; Franklin W. Knight 1977; Oostindie 1984.

5 For a classic statement, see Furnivall 1939:121 ('the Culture System grew until it overshadowed and blighted the whole economic organisation of the country, and nothing remained but the Government as a planter on a superhuman scale, with the NHM as its sole agent'). More recent literature, heavily focused on the impact of the Cultuurstelsel on the society and economy of rural Java (for example, Elson 1994), has done little to open up the subject, though much of the work of Robert Van Niel $(1992,2005)$ and Cees Fasseur $(1992,1996)$ is pregnant with implications. 
within the Indies colonial community were stifled, or at best relegated to the margins of society and economy, where such 'private' colonial entrepreneurial activity as did take place suffered from 'pariah' status. One highly respected commentator has remarked (albeit only in passing) on a 'twenty-year struggle of the Kultuurstelsel's beamtenstaat against private colonial capital (1848-1868)' ${ }^{6}$ A parallel reading stresses that the ostensible bourgeoisie - the contractors - that emerged within the confines of the Cultuurstelsel were, in reality, no more than the privileged clients or favoured concessionaires of a bureaucratic state. In modern parlance, they were 'ersatz' capitalists.

On neither of these broadly complementary readings did the Cultuurstelsel leave significant interstices in which colonial, 'domestic' capital might hope to develop and in which an Indies bourgeoisie might be expected to flourish. The historical consequences were potentially far-reaching. In the 1870s, under pressure from the metropolitan parliament, the Indies bureaucracy was forced to relinquish some of its economic control, though many facets of the Cultuurstelsel were phased out gradually rather than terminated suddenly. Commercial crisis in the following decade, however, when the world price of sugar suddenly fell by half, revealing that the industry required large-scale new investment if it was to survive, finally settled the issue. Given the way in which the Cultuurstelsel had worked against their interests, there was no substantial local, Indies bourgeoisie to take the place of the state, and the way was open for metropolitan Dutch financial and commercial interests to step in. In one form or another, they continued to hold sway until the transfer of power to the Indonesian republic at the end of the 1940s. In the wake of the Cultuurstelsel, in short, Java developed, on this scenario, along the 'classic' lines of a colony where the dominant dynamic was provided by metropolitan capital, albeit with significant variations brought about by the uncommon strength of its state bureaucracy.

What follows is a contrary argument. Contending that there was indeed a significant colonial bourgeoisie in mid-nineteenth-century Java (that is, from the 1850s to the 1880s), I argue that the state in which the bourgeoisie was situated was far less hostile to its evolution than has sometimes been imagined. To be sure, the mid-century decades were punctuated by significant and often heated disputes between manufacturers and the Indies government, often centring on the trade-off between the extent to which the industry could expect the state to continue to commandeer labour on its behalf and the conditions under which the industry could dispose of its output. ${ }^{7}$ This was no mere paper war. In 1864, for example, commenting on the ongoing

6 Anderson 1983:489. The concept of the colonial 'beamtenstaat' - run by a largely autonomous bureaucracy, largely for its own purposes - was given wide circulation by Harry J. Benda (1966:591). It reflects, however, a set of assumptions about the 'Indies state' that has a much older history.

7 Well-documented examples are to be found in Fasseur 1992:198-9 and Reinsma 1955:65. 
measures by the metropolitan government designed to 'reform' the relations between state and industry, the NHM's Batavia office observed that for the majority of factories the latest regulation threatened a total 'annihilation of their enterprise' and that 'the future of the industry has never seemed darker than at present' ${ }^{8}$ To focus on such quarrels, however, is bad history. Far from being representative of a fundamental and unswerving hostility to the emergence of 'private capital' on the part of state officials, such conflicts were an integral part of the dynamics of an emergent bourgeois regime.

More specifically, we need to take cognizance of the 'half-formed' character of the Indies colonial bureaucracy of the mid-nineteenth century; ${ }^{9}$ its 'porous' rather than autonomous nature; ${ }^{10}$ and the extent to which it was permeated (as a number of historians have been quietly insisting in recent decades) by family and familiar relationships that bound together the interests of state officials with sugar manufacturers, estate owners, and partners in the colony's leading mercantile houses. ${ }^{11}$ In this context, we also need to recognize that (contrary to lingering notions on this score) Java under the Cultuurstelsel was not a 'closed' colony shut off by government monopoly to all but 'official' Europeans and state clients. ${ }^{12}$ Another key reason for rejecting the assumptions of an older historiography, however, has to do with a positive reappraisal of the role of 'rent seeking' and 'cronyism' - modern parlance for the standard terminology of contemporary criticism of the mid-century contractors - in the evolution of capital. ${ }^{13}$

\section{Contracts, contractors and bourgeoisie}

The contract system lay at the heart of the Cultuurstelsel as implemented from 1830 onward. As far as the production of sugar was concerned, it entailed the granting of concessions that conferred on the recipient the exclusive right to manufacture sugar from cane produced in a designated area around their mills. Manufacturers, however, were divorced from the growing of cane itself, which took place under the supervision of government

$8 \quad$ '39e Jaarlijksch verslag van de Factorij der Nederl. Handel Maatschappij 1 July 1863 tot ulto. Juny 1864', pp. 35-45, inventarisnummer (inv.) 4550, in: Nationaal Archief, The Hague (hereafter NA), Archief Nederlandsche Handel-Maatschappij (NHM) 1824-1964, nummer toegang 2.20.01. For other contemporary comment on the difficulties facing the industry in the 1860s, for example, see Memorie suiker-industrie 1865; Millard 1869.

9 Sutherland 1979:16, 35. Major studies of the Indies bureaucracy include Van den Doel 1994; Fasseur 1999; Onghokham 1978; Rush 1990.

10 On the concept of a 'porous' state bureaucracy, see, for example, Weiss 1996:182-91.

11 For notable examples, see Van Niel 1964; Rush 1990:118-9, 147-9; Fasseur 1996; Bosma and Raben 2003.

12 For a cogent argument against this position, see Bosma 2005.

13 For a notable general discussion, see McVey 1992. 
officials and village headmen. Only when the cane was ripe was it (in effect) handed over to the manufacturers, who arranged for it to be cut and carted to their mills. For this work, and that of the mills themselves, they were supplied (in part or in total) with forced labour, levied for the most part from the villages surrounding their factories.

The first such contracts were issued at the beginning of the 1830s, and the last almost twenty years later. In addition to the terms relating to raw material and labour, they generally stipulated a fixed price for the finished product, at which price it had to be delivered to the government's warehouses for shipment and sale by the NHM. Equally important, an integral part of each contract was the provision of a substantial low-interest loan to cover all or part of the expenses involved in building and equipping a factory, and the provision of annual subventions of working capital. In short, in addition to privileged, low-cost access to labour and raw material, the contracts provided both cheap finance from the public purse and a guaranteed outlet for the bulk of the contractor's production.

By 1850 nearly one hundred such contracts had been dispensed under the Cultuurstelsel to sugar manufacturers scatted across the lowlands of East Java and the island's north coast. In total, the Indies treasury dispensed a sum of between seven and ten million guilders, over a period of nearly two decades, in the making of these contracts. ${ }^{14}$ Together with the advantages to recipients accruing from the access to raw material and labour, this sum formed the core of capital formation among an emergent bourgeoisie of sugar contractors and their associates. There were, of course, other export staples produced under the Cultuurstelsel, and hence there were contractors in crops such as indigo and tobacco. The system of indigo contractors did not survive beyond the 1830s, however, and tobacco, though regionally important, never fuelled the bourgeoisie in mid-nineteenth-century Java to anything approaching the extent that sugar did. Data available for the mid-1850s suggest that there were around 180 such contractors and administrateurs - the individuals left in charge of the factories in the absence of their owners. Of the contractors themselves, the majority were (at least nominally) in residence at the factories they owned, while a minority, amounting at this date to around 23 individuals, were currently domiciled overseas, exclusively in Europe. ${ }^{15}$

14 Governor-General J.J. Rochussen estimated in 1845 that around ten million guilders had been expended on loans to sugar, tea and tobacco contractors (Fasseur 1992:92, note 40). Since the capital required to process tea and tobacco was relatively modest (no expensive machinery was involved), it can be assumed that by far the greater part of this money went to sugar contractors. In 1844, for example, sugar contractors owed the government some seven million guilders in unrepaid long-term loans (Fasseur 1992:92).

15 For a residency-by-residency listing (circa 1856) of factories, their owners, general managers (administrateurs), and other interested parties, see Opname suikerfabrieken Java 1857. Though the copy used was a separately bound version in the library of the Koninklijk Instituut voor de 
A number of generalizations can be made about the contractors. The majority were people who had been born in Europe - most of them in the Netherlands but some of them in the United Kingdom. Some were new, or relatively recent arrivals in the Indies, but many others had previous careers in the Indies and extensive ties to the Indies-born Dutch colonial community. A minority of the names - 27 in all - listed among the contractors at this date were those of peranakan Indies-Chinese, who owned around a dozen of the colony's 95 contract factories. Java's peranakan were of Chinese descent who, like many of the Indies-Dutch, had been long-settled in the colony and were, to a degree, acculturated. Largely - though not exclusively - the sugar industry prior to 1830 and the inauguration of the Cultuurstelsel had been dominated by the Indies-Chinese. After that date they played a role that is a good deal more difficult to decipher.

Opium farm revenues, and the profits of the trade in Java's interior to which the farms gave de facto access, are generally considered to have formed the basis for capital accumulation among the Indies-Chinese element of the colony's nineteenth-century bourgeoisie (Rush 1990:83-107). Such capital was invested in the mid-century sugar industry to an extent that went beyond the minority Indies-Chinese presence among Cultuurstelsel contractors. The Indies-Chinese had capital invested with European contractors in 'backwoods' sugar-making operations on Java's government lands, and also, though substantiating data are weak, in the sugar industry that grew up in the Vorstenlanden from the mid-century onward. Equally, there is evidence that around the mid-century, Indies-Chinese mill owners were as keen to industrialize manufacturing techniques as were any of their European and Eurasian counterparts. ${ }^{16}$ It is possible, however, to overstate the degree of Chinese involvement in ownership of the industry ${ }^{17}$ and - more importantly - to misjudge its implications. The argument developed here is that it was crucial to the continuing industrial project in Java sugar in the second half of the nineteenth century that many of the Indies bourgeoisie, who owned the bulk of Java's factories, were able to draw on metropolitan links to European commercial and financial capital. On

\footnotetext{
Tropen in Amsterdam, the compilation forms part of Appendix $\mathrm{C}$ to Handelingen van de Tweede Kamer der Staten-Generaal 1862-1863.

16 For evidence, circa 1850, that Indies-Chinese sugar contractors in the Oosthoek were keen to invest in up-to-date vacuum pan technology in their factories, and that they utilized their local Dutch business connections to order the apparatus from Western European manufacturers, see 'Kontracten vervaardigen en verzending stoomtoestellen tot het kooken van suiker', inv. 3122, in: NA, NHM, nummer toegang 2.20.01.

17 The remark in Rush (1990:102), for example, that 'in the 1870s and 1880s nearly half the private sugar mills in Java were Chinese owned' is open to serious misinterpretation. The category of mills to which Rush refers (on evidence from consecutive issues of the Koloniale verslag) excludes all the (former) contract factories, at that date still by far the more important and productive sector of the industry. Nor does the reference to the number of mills convey the necessary vital information about productive capacity and output. An informed guess would be that many - though by no means all - such mills were backwoods outfits of small capacity.
} 
present evidence, at least, it is not likely that Chinese owners shared in that advantage.

It should be noted that the Europeans, who formed the bulk of the contractors by the mid-1850s, were, with some exceptions, newcomers to the sugar industry, though not necessarily to the colony. They might well have had (or have formed) ties with the existing Dutch colonial elite in the colony, but there is not much evidence that they drew capital from this source. Nor did their initial capital appear to come in any significant measure from European metropolitan sources. Indeed, the presumption must be that they were heavily, and in many cases almost totally, dependent on the largesse of the state for the capital that enabled them to become established as sugar manufacturers. By the 1850s, however, bourgeois capital accumulation in the sugar industry had already departed from its initial moorings, and became, as we shall see, ever more complex in the following three decades, as agencies other than the Indies state came to play an increasingly important role in capital formation. In the absence of complete data on bourgeois fortunes in mid-century colonial Java, a number of individual case histories will have to suffice as indicators of general trends.

\section{The Hofland Brothers}

Thanks to fictionalized Dutch accounts of their 'seignorial profligacy', Pieter and Thomas Benjamin Hofland are perhaps the best known of the so-called suikerlords (sugar lords) of mid-nineteenth-century Java. From the point of view of the present argument, what is also of consequence is that, for some years, they employed one of the best-qualified 'mechanics' in the entire colony (Bosma and Raben 2003:130). Also of interest is that these mid-century bourgeois, who grew rich by virtue of their sugar contracts in East Java, were also closely connected to Indies-Chinese business interests.

Arriving in Java from the Coromandel Coast in the 1820s, by the end of the following decade the Hoflands were said to be drawing the huge sum of 400,000 guilders a year from their contract factories in Pasuruan Residency in Java's Oosthoek (East Corner). ${ }^{18}$ In this part of the colony, with its rich soils and ready access to labour from nearby Madura, the government's contracts were widely, and probably correctly, regarded as quite disproportionately favourable to the fortunate concessionaires. Buoyed by these profits, and in partnership with J.E. Banck (another Oosthoek contractor), in 1839 the brothers Hofland purchased the Pamanoekan and Tjiassem estate in West Java, ${ }^{19}$ which had been heavily planted with coffee and had a seemingly rich potential for

18 See evidence cited in Elson 1979:73.

19 As elsewhere, I have retained the colonial-era spelling of the names of estates and sugar factories. 
sugar. The purchase was underwritten by the NHM to the tune of around one million guilders. ${ }^{20}$ The Hofland enterprises were, however, also partly financed by Indies-Chinese capitalists of East Java. At the beginning of the 1850s, it was reliably reported with regard to the recently deceased Chinese merchant Kwee Yang Ho (whose family also owned several contract factories in East Java) that the Hoflands owed him 'great sums of money'. ${ }^{21}$ Their partner, J.E. Banck, was likewise heavily involved with Indies-Chinese capitalists in East Java. ${ }^{22}$

\section{William Stavers: an Englishman with the right connections}

William Stavers (1789-1864) was an Englishman, born to the east of the City of London in the dockland-shipyard area of Rotherhithe. He deserves our attention for two reasons. First, his contract to manufacture sugar was quite possibly gained as a result of blackmail by one of his associates. Second, his sugar factory in East Java was one of the best equipped in the colony. Because Stavers is otherwise largely undocumented, it is worthwhile to go into some detail about his varied career. It is instructive as regards how people of small means but excellent connections could enter the ranks of the mid-century Indies bourgeoisie.

Stavers was the son of the master of a whaling ship. As a youth he was placed in the British navy, but 'not liking the sea life he entered the army' ${ }^{23} \mathrm{He}$ saw service in Java as a member of the English East India Company's 'expeditionary force' that occupied Java between 1811 and 1816, and participated in the sack by British troops in 1812 of the Sultan's palace in Yogyakarta, one of the two princely capitals of Central Java's Vorstenlanden. Life in the Vorstenlanden evidently agreed with him. Settling in Surakarta, the seat of the Sultan's co-ruler and rival, in 1814 he married the sixteen yearold Maria Smith (or Schmidt), the Eurasian daughter of a (retired) colonel in the Dutch garrison. He made a living as a merchant - he was the local agent

20 The NHM's Batavia Factorij advanced the Hoflands more than one million guilders to buy Pamanoekan and Tjiassem, on the security of its output of sugar and coffee. See Factorij to Amsterdam, 5-9-1840/1527, inv. 7334; Factorij to Amsterdam, 29-11-1841/1819, inv. 7335, in: NA, NHM, nummer toegang 2.20.01.

21 See 'Kontracten vervaardigen en verzending stoomtoestellen tot het kooken van suiker', inv. 3122, in: NA, NHM, nummer toegang 2.20.01. For the Kwee family, and for their factories in East Java in the mid-1850s, see Salmon 1991:84; Opname suikerfabrieken Java 1857.

22 In addition to being the contractor for two large factories in Pasuruan Residency, Banck (born in Schleswig 1797, died in The Hague 1857) was also a partner, together with the heirs of the leading East Java merchant The Goan Tjing, in the contract for the Tjandie sugar factory in neighbouring Surabaya. See Opname suikerfabrieken Java 1857; Tjoa Tjwan Phing and Moolenaar 1957:15-22

23 For this and other details of William Stavers's life, see the 'Journal' of his brother Thomas Reed Stavers, at http://www.du.edu/ ttyler/ploughboy/trstaversjournal.htm. Other sources of information appear in the relevant notes. 
for the major Batavia firm of MacQuoid Davidson \& Co. - and coffee planter, on land leased from members of the ruler's family. ${ }^{24}$ The Stavers were still living in the Vorstenlanden in 1821, when their young daughter died there of cholera (Nahuys van Burgst 1852:130). Finacially, however, the family were evidently prospering, since in the following year, accompanied by his wife and remaining child, Caspar William, Stavers travelled to London, only returning (with a new born daughter) when he heard that the Indies government had revoked the leases on which his coffee wealth depended. ${ }^{25}$

The excellent connections he had established with the princely house of Mangkunegara in Surakarta enabled him to remain there when other planters were expelled on orders from Batavia in 1823. Indeed, Stavers was reportedly the intendant-generaal of all the Mangkunegara's estates. In 1825, when the Java War broke out between the Dutch and the rebellious Javanese aristocrat Pangeran Dipanagara, Stavers was well placed to put his military experience to good use and performed sterling service for a grateful colonial government. According to the account related to his father by the young Dutch patrician Willem van Hogendorp (in Java as Secretary of Commissioner-General Léonard du Bus de Gisignies), Stavers at various times both fought against - and attempted to negotiate with - Dipanegara and his supporters, and had his house burnt down and his estates laid waste by the insurgents. ${ }^{26}$ The Dutch conferred on him the military Willemsorde (Fourth Class). Sometime after the war ended, he relocated to East Java, where, early in the 1830s, he became involved in the area's burgeoning sugar industry. It does not appear to have been an entirely happy experience. One of the letters of the great Calcutta merchant John Palmer to his Batavia commercial correspondent Gillian Maclaine speaks of 'poor Jack [William] Stavers [...] reduced to a sugar plantation after his enterprising, spirited and useful toils in various more distinguished courses of life. But he is well and in high feathers, you say [...] and can never lose the regard of his old friends and the respect of new people, and that is affluence enough for an honest man. ${ }^{27}$ Honest man or not, in 1833 he

24 Stavers's connection with MacQuoid Davidson emerges from the copy of the contract for the winding up of his (Boudet's) estate, contained in (ex-) Vorstenlanden planter J.D. Boudet's 'address' to the Dutch king, Willem I (circa 1826). See Verbaal 17-11-1826/56, inv. 531, in: NA, Archief Ministerie van Koloniën (hereafter Min. Kol.) 1814-1849, nummer toegang 2.10.01.

25 For Stavers's departure from Batavia (16-6-1822), the family's subsequent return and the rumours that had reached him about the annulling of the leases, see Bataviasche Courant 22-61822/25 and 13-11-1824/11; Stavers to Nahuys, 17-10-1823, Mss 616, Vol. 8, no. 3, in: Universiteitsbibliotheek, Leiden, Collectie Nahuys.

26 On Stavers's connections with the Mangkunegara and his exploits during the Java War, see Willem van Hogendorp to G.K. van Hogendorp, 28-8-1826, p. 9, and 26-9-1827 (unpaginated) inv. 91, in: NA, Collectie G.K. van Hogendorp, nummer toegang 2.21.006.49.

27 John Palmer to Gillian Maclaine, 6-4-1833, Eng. Lett. C 123, p. 387, in: Bodleian Library, Oxford, Letter Books of John Palmer. A few months earlier, Palmer had written to Maclaine's business partner Edward Watson that 'You give me much concern about Stavers, and I shall be very anxious for your next account and to know that he is prospering [...]', Palmer to Watson, 13-111832, Eng. Lett. C 106, p. 130, in: Bodleian Library, Oxford, Letter Books of John Palmer. 
appears to have been banned temporarily (on account of an altercation with the Javanese regent) from the East Java locality where he had been employed as overseer at the Oembol sugar factory, owned by another Java domiciled Englishman, Charles Etty. ${ }^{28}$ Later in the 1830s, according to his brother Thomas Reed Stavers's account, he part-owned a small foundry in the East Java town of Pasuruan. By the end of the decade, however, he had returned to England, where a further venture, involving running a coastal steamer, appears to have met with little success. At this point his luck changed when he took himself to The Hague and, after seeking the help of Dutch friends, obtained a government contract for the manufacture of sugar.

William Stavers's contacts in Holland included the influential and ambitious Colonel H.G. Nahuys van Burgst. Having been the Dutch resident at the court of Yogyakarta and, subsequently, Surakarta, Nahuys was an old acquaintance from the days of the Java War and earlier. ${ }^{29}$ Together with the wealthy, repatriated contractor and merchant J.E. Banck, he stood collateral for the loan that was part of the contract that Stavers was eventually awarded. Stavers's usefulness to his new partners was no doubt his extensive knowledge of - and wide circle acquaintance in - East and Central Java, where a residence of nearly a quarter of a century had left him with excellent contacts. For example, when, in March 1840, his brother Thomas Reed Stavers arrived in Java's Oosthoek, together with his wife Fanny, fresh from a voyage from Europe, the couple were evidently pleasantly taken aback by the welcome that they received in the local colonial community. Arriving back in Java in the following year, William Stavers himself was evidently meant to be the partnership's 'man-on-the-spot', whose prior experience of the sugar industry was also an advantage. From the point of view of Stavers's

28 William Stavers appears on a contemporary list of sugar contractors. See 'Aantooning der op Java gevestigde suiker etablissementen tengevolge van gesloten contracten met het Gouvernement', 11-9-1834, inv. 3203, in: NA, Min. Kol. 1814-1849, nummer toegang 2.10.01. However, while the list notes contracts for the cultivation of cane, it names no sugar factory in connection with Stavers. A year earlier, in 1833, a William Stavers (presumably the William Stavers since his son was called Caspar), described as overseer (opziener) at the Oembol sugar factory in the East Java district of Probolinggo, had been temporarily banned from the area after complaints by the regent. Oembol was owned by the 'pioneer' sugar contractor Charles Etty. (According to Thomas Reed Stavers's 'Journal', Etty remained a good friend of the family up to his death in 1856.) See 'Register der handelingen van den Gouverneur-Generaal van Nederlandsch Indië in Rade over den maand Januari 1834', 17-1-1834/9, inv. 2847, in: NA, Min. Kol. 1814-1849, nummer toegang 2.10.01.

29 Toward the end of the war, Stavers had been allowed to lease a coffee estate, at Blitar in Surakarta - an arrangement in which it may be suspected that Nahuys (at that time resident at the court of Solo) was the major stakeholder. On Stavers's lease on Blitar (and loan of $f$ 10,000 from the Indies Government to develop the estate), see 'Register der handelingen van den Gouverneur-Generaal van Nederlandsch Indië in Rade over den maand December 1829', 7-12-1829/4, inv. 2832 and 'Register der handelingen van den Gouverneur-Generaal van Nederlandsch Indië buiten Rade over den maand April', 10-4-1829/1, inv. 2527 in: NA, Min. Kol. 1814-1849, nummer toegang 2.10.01. 
contacts in the Netherlands, however, his local knowledge was only part of his attraction: the other part was that his own, evidently precarious finances meant that he had little choice but to accede to an 'underhand' arrangement whereby, once he had gained a sugar contract, he signed over the moiety to a third party who, as a serving official of the Indies Government, could not himself own a contract, but who was most likely the driving force in the whole arrangement.

This other person involved in Stavers's sugar contract, albeit covertly, was the Dutch nobleman R.L. van Andringa de Kempenaer. His intervention, which led to his becoming a major stakeholder in the contract, may have been the critical factor in its being granted. As an officer in the Indies army, Van Andringa de Kempenaer had fought, like Stavers himself, in the Java War; he was an associate of Nahuys; most important of all, he is widely thought to have been blackmailing the newly enthroned Dutch king, Willem II. ${ }^{30}$ Presumably more than coincidently, by the mid-1840s Stavers and his associates had been granted state loans of nearly 700,000 guilders (charged to the Indies treasury), by far the largest sum of money advanced to any midcentury contractor. ${ }^{31}$ These people were, however, entrepreneurs as well as blackmailers: they spent at least part of their gains on one of the most up-todate and best-equipped factories in Java. Appropriately enough, they called it Koning Willem II. ${ }^{32}$

\section{Theodore Lucassen: the Dutch gentry and the sugar bourgeoisie}

Theodore Lucassen's ancestors were country gentry from the borderlands of the Netherlands and Germany. He was born in a castle (ridderslot), entered the army early enough to be captured in Napoleon's campaign in Russia, and was repatriated soon enough to join the first Dutch military contingents dispatched to Java in 1816, when the colony was restored by the British. His first wife was a colonial-born woman of a reasonably 'good' family, but it was most likely his earlier connections, gained in the military prior to leaving Holland, that helped him achieve the rank of colonel as he rose in the Indies to the position of chief of staff, Military Administration (1833-1837). J.C. Baud, governor-general, minister of colonies, and power-to-be-reckoned-with in Dutch colonial circles, appears to have had a poor view of Lucassen (he deplored his 'hankering after the old ways'), ${ }^{33}$ but this did not

30 On Van Andringa de Kempenaer, see Baud 1983, I:167 and the references therein.

31 Fasseur 1992:187. The precise sum was 673,000 guilders.

32 On the technologically advanced character of the Koning Willem II factory, see Leidelmeijer 1997:150-3.

33 Baud to Van den Bosch, 29-7-1835, in Westendorp 1956, II:180. 
prevent Lucassen from obtaining a sugar contract after his retirement to the Netherlands at the end of the 1830s. Knowing the right people, and having an ambitious plan for advanced manufacture, he evidently won the favour of the King; schemes of that kind were dear to Willem I's heart, and he put enough pressure on the Colonial Office to secure Lucassen a contract in the face of opposition from the authorities in Batavia. ${ }^{34}$

The Colonel hence returned to the Indies with a shipload of new equipment, for setting up two sugar factories, from the same leading FrancoBelgian firm of manufacturers, Derosne \& Cail, who had supplied Stavers. The enterprise was not without mishap; his first cargo was lost when the ship was wrecked off Bali. By 1843, however, Lucassen and his ménage - which included a young steam technician and sugar maker (Hubertus Hoevenaar), who had served an apprenticeship in John Cockerill's iron foundries and engine works at Seraing (near Liège), then the largest of their kind in continental Europe ${ }^{35}$ - were solidly established among the rice fields and denselysettled villages of the lowlands of Tegal, on the north coast of Central Java.

Colonel Lucassen subsequently returned to Holland, and died in The Hague in 1854. Two of his sons, Donald and Reinier, carried on the business in Java, their influence much enhanced in both colony and metropolis by their father's second marriage (in 1832) to a Dutch-born woman, Susanna Pietermaat. Her father was a very senior Indies official (he died in office as Resident of Surabaya in 1848), and her sisters were married to a future governor-general and colonial minister (Pieter Mijer), and to a member of the Raad van Indië (Council of the Indies, the colony's supreme advisory body). ${ }^{36}$ Among the Lucassen connections in the Indies, moreover, was another brother-in-law, Otto van Rees, the coming man of the Indies bureaucracy. ${ }^{37}$

The younger Lucassens parlayed this influence in Batavia to good effect. At the end of 1850s, they arranged to have the conditions of their contract adjusted to give them control over most of their output (which had previously been delivered to the Indies government's warehouses at a fixed rate). 'Cronyism' indeed - and it was met with impotent rage in the Colonial Office in The Hague - but the young men used their new advantage in a thoroughly bourgeois manner, by securing a large loan from the NHM (the beginning of the family's long-standing connections with the firm). This enabled them not only to consolidate their inheritance (there were other heirs to be bought out)

34 On Theodore Lucassen's involvement in the sugar industry, see Leidelmeijer 1997:155-70. For the Lucassen family, see Nederland's Patriciaat, 5 (1914), pp. 269-77; 21; 53 (1967), pp. 168-78, and see further Th. Lucassen to Baud, 27-3-1845, inv. 723, in: NA, Collectie J.C. Baud, nummer toegang 2.21.007.58.

35 Leidelmeijer 1997:158. On Cockerill's Seraing works, see Pasleau 1992:35-77.

36 See under 'Pietermaat' in Nederland's Patriciaat, 12 (1921-22), pp. 390-2.

37 On Van Rees, see Fasseur 1996:113-51. 
but also to renovate their factories, partly through the purchase of a 'state of the art' steam mill from a leading British supplier. ${ }^{38}$

\section{Johannes Herderschee: bourgeois entrepreneur on the edge of the Cultuurstelsel}

Though they formed the core of the sugar bourgeoisie of mid-nineteenthcentury Java, however, the contractors and their immediate associates were far from being its only constituents. In the government lands of Java (that is, the directly administered territories, excluding the quasi-autonomous Vorstenlanden), there were people involved in agricultural ventures who were not themselves contractors, but who indubitably formed part of the bourgeoisie. Even more to the point, in the Vorstenlanden of Central Java there was an important group of sugar (as well as coffee and indigo) growers and manufacturers who formed the bulk of that part of the mid-century bourgeoisie that existed largely apart from the immediate operation of the Cultuurstelsel. Somebody who linked all three categories - the contractors, the 'private' entrepreneurs, and the planters operating in the Vorstenlanden - was the Dutch businessman and sugar manufacturer Johannes Eliza Herderschee (1813-1862).

During the 1830s, Herderschee, Amsterdam-born but long domiciled in the Indies, was established as a commodity merchant in Batavia. He belonged to The Star in the East Freemasons' Lodge; was an officer of the city guard (schutterij); and - suggestive of well-rounded bourgeois interests - was a member of both the Bataviaasch Genootschap van Kunsten en Wetenschappen, one of the oldest such foundations in the colony, and the recently founded Nederlandsch-Indische Maatschappij van Nijverheid. ${ }^{39}$ During the course of the following decades, he came to own a major sugar factory on the north coast of Central Java and another in the Vorstenlanden. ${ }^{40}$ In addition to this, however, he also had a presence within the contract system established under the Cultuurstelsel. His sister-in-law was the daughter of the well-known sugar contractor Louis Vitalis, whose Sragie factory in Central Java's Pekalongan Residency was an enterprise that Herderschee himself at one time both financed and managed. ${ }^{41}$ His several enterprises drew for capital on a relative-

38 See Verbaal 20-10-1859/17, inv. 879; Exhibitum Geheim 29-2-1860/54, inv. 5910, in: NA, Min. Kol. 1850-1900, nummer toegang 2.10.02; Notulen NHM Factorij Batavia 29-9-1858/409; 1-31859/449; 17-9-1859/512; 17-1-1860/549, inv. 9252-9254, in: NA, NHM, nummer toegang 2.20.01.

39 Respectively, the Batavia Society of the Arts and Sciences, and the Netherlands Indies Society for Industry. See De Neve en Van Duijn 1994:205.

40 He owned the Tjepper sugar factory in Solo. See 'Registers houdende inschrijvingen van overeenkomsten met diverse suikerfabrieken, 1858-1879', p. 47, inv. 4978, in: NA, NHM, nummer toegang 2.20.01.

41 Krajenbrink 1866:72. On the Herderschee family's relationship to Vitalis, see De Indische Navorscher 1 (1934) p.16. 
ly small loan (160,000 guilders) from the Widows Pension Fund for Officers in the Netherlands Indies Army; on very much more substantial loans, allegedly around 1.7 million guilders, from the major Batavia firm of Van Ommeren, Rueb \& Co.; and on the investments of a number of private individuals in the colony, amounting perhaps to another 700,000 guilders. ${ }^{42}$

He was, in short, a major bourgeois entrepreneur whose interests spanned the spheres of state and 'private' enterprise in mid-century Java. Indeed, on this and other evidence it seems best to conclude that the divide, heavily in evidence in contemporary polemic, between 'state' (Cultuurstelsel) and 'private' in the commercial and planter world of mid-nineteenth-century Java, was at least as porous as it was contested. ${ }^{43}$ To be sure, Herderschee himself came to prominence shortly before his death in 1862 through his role in the Simbang Affair, in which he found himself - at least according to his own account - pitted against the Indies government's resident in Pekalongan, F.H.J. Netscher. This affair (if such it was), however, ended in Netscher's discomfiture and premature retirement to Holland - hardly an indication of the all-consuming beamtenstaat alluded to earlier, in which the interests and agendas of an essentially homogenous and autonomous officialdom enjoyed a largely unquestioned dominance.

\section{Between colony and metropolis}

At the end of the 1840s, the travel time between Southeast Asia and Europe was dramatically reduced to a degree that would not occur again until the introduction of the aeroplane some eighty years later. The time taken for the well-heeled passenger to travel between the United Kingdom and Singapore was reduced to as little as 39 days, whereas until then it had taken up to four months, or even longer if adverse weather was encountered in the Atlantic or round the Cape of Good Hope. The new overland mail route that made possible this drastically shortened schedule via the Red Sea, Suez, Cairo, and Alexandria was contingent on regular paddle steamer voyagers that converged on the Egyptian land-bridge - the famous canal was still three decades off - from both west and east. ${ }^{44}$

42 'Registers houdende inschrijvingen van overeenkomsten met diverse suikerfabrieken, 18581879', p. 47, inv. 4978, in: NA, NHM, nummer toegang 2.20.01; Netscher 1864:41-3.

43 For a brief, cogent recent argument about the existence of the 'private' sector, see Houben 1993.

44 For published experiences of the 'overland' route in the mid-century, see Junghuhn 1851:4-14; Gevers Deynoot 1864:1-25. The journey time of 39 days (1863) from Southampton to Singapore is from 'Journal of Thomas Reed Stavers 1798-1867', p. 39, at http://www.du.edu/ ttyler/ploughboy/trstaversjournal.htm. 
Contrary to the supposed cultural and social remoteness between colony and metropolis, and the physical stress imposed by the journey - as embodied in the myth of tempo doeloe - the factor of distance was far less prohibitive than is sometimes imagined, with Dutch colonial elites in the Indies having had a long history of continuous contact with their counterparts in the Netherlands. As Ulbe Bosma (2007) has recently argued, such ties with the metropolis were a vital element in the perpetuation of bourgeois status in the colony. Instead of isolation and remoteness, we need to imagine a bourgeoisie who regularly sent their children 'home' for education, who sought marriage partners to cement a nexus that was at once colonial and metropolitan, and whose various branches of extended families had business interests in both Java and Europe.

Over time, this pronounced degree of contact between the Indies and Holland provided an important, possibly the critical, dynamic of bourgeois capital formation in colonial Java between the 1850s and the 1880s, and challenges the binary of 'metropolis' and 'colony' central to an older historiography of the period. In so doing, moreover, it enables a fresh look at the purported rescue of a hitherto isolated 'colonial' industry by the metropolitan bourgeoisie in the wake of the crisis of 1884, when the Java manufacturers faced ruin as a result of the crash in world sugar prices.

\section{Java's industrial sugar mills}

The story begins in the late 1840s. In 1847, the Indies government, which had hitherto primed the pump of bourgeois capital accumulation by providing the bulk of the capital flowing into the industry, stopped making capital loans to contractors. A little over a decade later, at the beginning of the 1860s, the government also withdrew from the business of providing annual subventions of working capital (Fasseur 1992:92-3). For the previous two decades, state financing of this kind had fostered a substantial degree of technological innovation in the industry. At mid-century, nonetheless, state-of-the-art factories like those of Lucassen and Stavers, equipped with the latest in steam-operated boiling houses imported from leading European firms, remained very much in the minority. Within ten years, however, approximately half of Java's contract sugar factories were equipped with the vacuum pans (of one kind or another) that revolutionized sugar manufacture world-wide in the midnineteenth century by enabling condensed cane juice to be boiled into sugar at a low temperature made possible by reduced air pressure. ${ }^{45}$ Added to that,

45 For substantiating data on the technology of production in Java prior to the 1870 s, see Leidelmeijer 1997:138; Koloniaal verslag 1867-68:124; Van Gorkom 1879:285. On the technological revolution in sugar manufacture in general in the course of the nineteenth century, see in particular Deerr 1949-50; Lock, Wigner and Harland 1882; Soames 1872; Wray 1848. 
between the mid-1870s and the onset of the crisis of 1884, one third or more of Java's major sugar factories were equipped with multiple effect condensers that carried the principle of the vacuum pan further down the production line, so that the risky business of clarifying and reducing the raw cane juice took place in a totally enclosed system based on the recirculation of steam heat. As well as offering more of a significantly improved product, the multiple effect condenser offered massive savings in fuel consumption. ${ }^{46}$ Elsewhere in Asia, the only such sets of equipment found prior to the twentieth century were located in the sugar refineries of Hong Kong, while in the New World only the most advanced industries possessed them. In variance with the still lingering image that the era of the Cultuurstelstel left the Java industry in poor technological shape not remedied until 'after metropolitan capital took over after $1884^{\prime}$, the truth is that many of the Java factories were well up to international best-practice manufacturing standards before the crisis hit them.

Far from being a moribund remnant of the Cultuustelsel, the Java industry of the 1870s and early 1880s was a great importer of new machinery of all kinds. Exclusive of equipment brought into Java to service the beginnings of the expansion of the island's rail and tramway network, machinery to a total value of 26,254,000 guilders was imported into Java during the period 1875-1884: a figure only around 35\% lower than that of the following decade, when the full resources of metropolitan capital were being brought to bear on the industry's requirements. Indeed, the value of machinery imported in 1884 alone $\left(5,678,000\right.$ guilders) was only twice exceeded during the century. ${ }^{47}$ Money in these quantities could buy a lot of new equipment, even entire factories. A quarter of a million guilders was more than enough to buy all the equipment needed for a state-of-the-art operation in the early 1880s (the sum included freight and insurance), while the simpler of the multiple effect condensers (achieving a triple rather than quadruple effect) cost around 40,000 guilders. ${ }^{48}$

46 The first multiple effect appears to have been installed at the Tjipiring factory in Semarang Residency in 1875 (Koloniaal verslag 1877:197). From data in the Koloniaal verslag for the years 1875 and 1881, it can be seen that at least 27 multiple effects were installed Java-wide in those years. Between 1882 and 1885 the Koloniaal verslag contains no such specific information - but there is no reason to suppose that the pace had slowed. Indeed, it almost certainly speeded up and it is safe to assume that there were more than 50 multiple effects in operation in Java by 1885 .

47 Korthals Altes 1991:118-24. A further index to improvements in manufacture is provided by data on productivity, measured in terms of weight of sugar per hectare of harvested cane produced by the contract factories - a crude gauge but in this context a reasonably satisfactory one, since there is little reason to suppose that in the 1870 s there were any major improvements in the cultivation of cane resulting in higher sugar yields. Productivity measured in terms of weight of sugar to area of plantation in 1872 stood at around 5.6 tons per ha, whereas in 1884 it was around 8.1 tons. Calculated from Creutzberg 1975: Table 7, lines 8, 30, 32.

48 For equipment costs, see for example, J.C.F. Schor, 'Gedenkboek Koloniale Bank', pp. 22-6, circa 1945, inv. 883, in: NA, Archieven der Cultuur-, Handel- en Industriebank 'Koloniale Bank/ Cultuurbank NV' 1881-1969 (Koloniale Bank), nummer toegang 2.20.04 (Schor was the director of the Koloniale Bank from 1940 to 1945); 'Jaarverslag Factorij Batavia', 1881, p. 52, inv. 4552, in: NA, NHM, nummer toegang 2.20.01. 


\section{Support for the industrial project}

Initial support for this ongoing industrial project, once the state itself had withdrawn from direct financing, came from the Factorij, the Batavia branch office of the NHM. During the 1850s and 1860s, acting semi-autonomously, the Factorij developed extensive financial links with the sugar industry (indeed, the NHM was eventually to transform itself from a trading company into a bank). Some of its investment took the form of working capital, provided on an annual basis and in return for consignment of that year's output. Altogether more important, however, were the capital loans that the Factorij made to individual producers, secured in the form of mortgages on their factories. During the 1860s through to the mid-1870s, with a falling off from 1867 onward, a rough calculation would be that the NHM Factorij invested nearly six and a half million guilders in the sugar industry in the form of mortgages (this calculation excludes working capital provided in return for consignment contracts). ${ }^{49}$

It would be possible, of course, to construe the role of the NHM as evidence that the Indies bourgeoisie was too underdeveloped to take over where the Indies government had left off, and that in consequence the financing of the industry had to be taken over by a body intimately linked to the Indies state. More plausible, however, is the view that NHM's Batavia Factorij in the mid-century decades was so effectively 'infiltrated' by colonial interests as to become, at least temporarily, the flagship (along with the Javasche Bank $)^{50}$ of the emergent Indies bourgeoisie. During the period 1840-1880, prime evidence for this is that the senior management of the Factorij was largely composed of individuals who had 'come out' to the Indies as young men in junior positions and who had been absorbed through marriage and acquaintance into the Indies milieu - more specifically, into the ranks of the Indies bourgeoisie. Notably, only one president of the Factorij during this period (the resonantly named Nicholaas van Taack Tra Kranen, 1859-1866) was an 'expatriate' manager, sent out from the metropolitan head office, and his dispatch was a highly particular response to the murder of his recently appointed predecessor by a household servant. ${ }^{51}$

49 'Register der overeenkomsten', inv. 4976-4982, in: NA, NHM, nummer toegang 2.20.01; Mansvelt 1924, II:357-63.

50 For a reassessment of the Javasche Bank's role in assisting the growth of the Indies bourgeoisie, see Claver 2006. It should be noted, however, that the Bank's statutes prohibited it from becoming a direct investor in the sugar industry or any other agricultural ventures. This appears not to have stopped it, however, from lending money to firms that did directly invest.

51 See the genealogy of the leading personnel of the NHM Factorij Batavia, 1826-1884, researched by Peter Christiaans, forthcoming in De Indische Navorscher. On the murder of Jan Constantin Teengs in June 1859, see 'Vergadering van Dingsdag den 14en Juny 1859', no. 481; 'Vergadering van Donderdag den 16en Juny 1859', no. 483; Telegram Factorij aan Amsterdam, 23-6-1859, inv. 4247, in: NA, NHM, nummer toegang 2.20.01. 


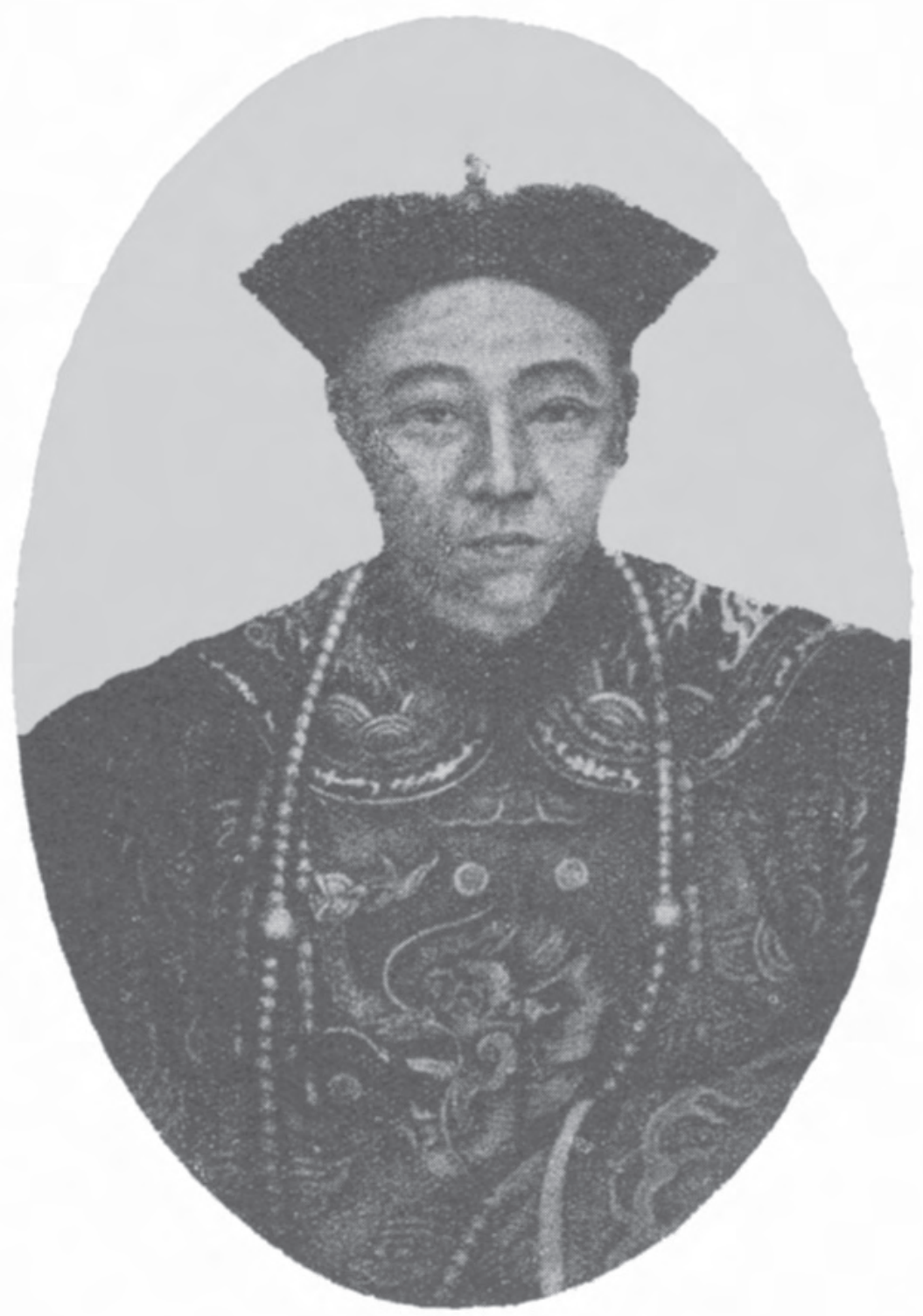

The Goan Tjing, co-founder of Tjandi sugar factory (Tjoa Tjwan Phing and Moolenaar 1957) 
Consistent with this local identification was the Factorij's vigorous advocacy during the 1860s of the interests of Java's colonial sugar factories against attempts by the metropolitan government to alter the terms on which the industry interacted with the state. ${ }^{52}$ Equally indicative was the Factorij's behaviour toward its Java clients: in the mid-1870s, for example, the Factorij extended further credit to bail out Donald Lucassen (one of the late colonel's two sugar manufacturer sons) at his Tegal factory, ignoring the telegraphed protest from the corporation's Amsterdam office (11-10-1876) that 'we do not approve transaction entered into regarding Doekowringin'.$^{53}$

\section{Mercantile firms and the sugar industry}

In the 1850s and 1860s, moreover, the NHM Factorij was not the sole source of finance available to the colony's sugar manufacturers, though it was probably the most important one. ${ }^{54} \mathrm{NHM}$ investment was at its greatest in the 'sugar belt' along the north coast of Central Java, but fairly weak in the rich sugar districts of East Java. There and elsewhere, notably in the Vorstenlanden, close links with the colony's leading commodity trading firms meant that manufacturers could hope to draw on mercantile capital other than that represented by the NHM.

The upsurge in sugar production in the colony from 1840 onward - within some thirty years Java became the world's second largest supplier of cane sugar (after Cuba) to world commodity markets - created rich opportunities for the growth of mercantile capital in the colony. This led to a significant further fuelling of the bourgeois impulse in the mid-century. The emergence of an Indies bourgeoisie was based not simply on the manufacture of sugar but also on the sugar trade. In short, the formation of mid-century colonial bourgeois capital resulted from an international commodity trade fed by the output of the Cultuurstelsel, and the associated growth of mercantile houses at Batavia and the other major ports of Semarang and Surabaya. It is the case, of course, that this development was also stimulated by the market for imported goods that the Cultuurstelsel appears to have promoted among those minority elements of the rural population that benefited from it. All the same, it looks as if the key factor was the profits from the trade in sugar which, from the mid-century onward, came increasingly into the hands of locally based mercantile houses and their overseas connections.

The issue of colonial trade and capital formation within the colony is an important one. Again, what I question here is the assumption that mid-nine-

52 See, for example, '39e Jaarlijksch verslag van de Factorij der Nederl. Handel Maatschappij 1 July 1863 tot ulto. Juny 1864', pp. 35-45, inv. 4550, in: NA, NHM, nummer toegang 2.20.01.

53 'Register der overeenkomsten', inv. 4976-4982, in: NA, NHM, nummer toegang 2.20.01.

54 For a succinct preliminary discussion of sugar finance, see Fasseur 1992:92-4. 
teenth-century trade (as under the VOC a century earlier) was largely in the hands of a monopolistic state and its commercial 'subsidiary', the NHM. By 1860 , in terms of value, firms other than the NHM accounted for $46 \%$ of the Netherlands Indies' total export trade, and for some $65 \%$ of the export value of Java sugar itself. A decade later, in 1870, the comparable figures were 51\% and $72 \% .{ }^{55}$ In summary, between 1850 and 1870 the greater part of Java's sugar export was in 'private' hands rather than in those of the NHM.

As far as the contract factories were concerned, the immediate point of connection with the growing colonial mercantile community of Batavia, Semarang and Surabaya was the insistence of the Indies government on guarantors (borgen) for the contracts that the concessionaires entered into. Some of these guarantors were people of little substance or, somewhat surprisingly perhaps, other contractors. Many of them, however, were partners in the colony's European mercantile houses, attracted no doubt by the possibility of favourable access to the manufacturers' 'free disposal' sugar' ${ }^{56}$ or seeking to assure the investments of principals in Europe. The Batavia firms of Reijnst and Vinju, for example, stood as guarantors for the contracts of several East Java sugar factories in which their correspondents in Holland, the great Rotterdam firm of Van Hoboken, also had an interest. ${ }^{57}$ Another longstanding Batavia firm, Paine Stricker \& Co., was connected in Amsterdam with the major business house of Van Eeghen, while in Java two of the firm's partners were guarantors for a quasi-contract sugar factory on the north coast of Central Java whose output they no doubt acquired in return. ${ }^{58}$

In this context of the mercantile dimensions of the sugar bourgeoisie, the failure of a number of investments (there is no indication that sugar was central to the crisis) in the 1860s led to several major bankruptcies in 1862-1863. They included that of the Batavia firm of Van Ommeren, Rueb \& Co., which had been in business for more than twenty years and was until then regarded as one of the 'most solid' of Java's European mercantile houses: Willem van

55 The relevant data (and an authoritative commentary) is in Korthals Altes 1991:13, 142-6. Others have, of course, touched on the point, for example, Houben 1993:52.

56 At the beginning of the 1850 s, around $25 \%$ of the sugar produced by contract manufacturers was 'free disposal', that is they could sell it on their own account rather than deliver it to the government. See Fasseur 1992:91-2.

57 Van Hobokens were initially associated in two East Java sugar factories with J.E. Banck and took them over from him in 1853. See Baud 1983, I:126 and the references therein.

58 New England-born businessman A.A. Reed and the Dutchman E.W. Cramerus were guarantors for the Lemahabang factory in Tegal Residency. For details on Paine Stricker's partners and the firm's connections, see 'Staat der verschillende kultuur-inrigtingen onder ultimo December 1861; Suiker-kultuur', Exhibitum 29-1-1863/5, in: NA, Min. Kol. 1850-1900, nummer toegang 2.10.02; Van Niel 1964:224-30; Rogge 1949:206-66. Paine Stricker had interests in other sugar factories in Cirebon and Krawang, for which Reed and Cramerus also acted as guarantors. See 'Staat der verschillende kultuur-inrigtingen onder ultimo December 1852; Suiker-kultuur', Exhibitum 17-3-1854/4, inv. 324; 'Staat der verschillende kultuur-inrigtingen onder ultimo December 1853; Suiker-kultuur', Exhibitum 21-3-1855/15, inv. 409, in: NA, Min. Kol. 1850-1900, nummer toegang 2.10.02. 
Ommeren had been on the board of directors of the Javaasche Bank, the colony's main financial institution, and both he and his partner, William Rueb, came from substantial merchant families in Rotterdam. ${ }^{59}$ A major contributing factor was the sudden death of Johannes Herderschee in May 1862, an event said to have exposed debts in the region of 2.7 million guilders - the lion's share of which was said to be owed to Van Ommeren, Rueb \& Co. (Netscher 1864:41-3).

Though the crisis of 1862-1863 clearly caused a deal of short-term havoc, the secular trend was toward growth in investment in sugar by the cream of Java's mercantile bourgeoisie. One of the key companies was the Maclaine Watson 'group', consisting of a trio of firms based in Batavia (Maclaine Watson), Semarang (Macniell \& Co.), and Surabaya (Fraser Eaton \& Co.). All three were founded in the same decade - the 1820s - and their interests, commercial and plantation, sprawled across Java. The founder of the Batavia house, Gillian Maclaine (1798-1840), had married very well indeed into official and 'old' landowner circles in the colony, and one of his successors in the business, his cousin Donald Maclaine of Lochbuie, did even better: among his in-laws was both a governor-general and the president of the NHM Factorij. ${ }^{60}$

The Maclaine businesses were big in the 'private' sector, and at one stage had extensive investments outside the government sphere in the Vorstenlanden. At the same time, however, they were also heavily involved in the Cultuurstelsel, as 'contract' factory owners, financiers, and guarantors of other contractors. In the 1850s, for example, one of the partners in Fraser Eaton was also co-owner of a factory in Kediri in East Java, ${ }^{61}$ while in West Java Maclaine Watson owned at least one major sugar factory, in Cirebon Residency, ${ }^{62}$ and no doubt had consignment contracts and other arrangements with a number of others. At the onset of the sugar crisis of 1884 they and their associates in Semarang and Surabaya were reliably reckoned to have bought around $40 \%$ of the colony's total sugar crop (presumably at a good price, since they survived the experience), much of it from factories 'in which they had an interest'. ${ }^{63}$

\footnotetext{
59 '38e Jaarlijksch verslag van de Factorij der Nederl. Handel Maatschappij 1 July 1862 tot ulto. Juny $1863^{\prime}$, pp. 20-5, inv. 4550, in: NA, NHM, nummer toegang 2.20.01. For Van Ommeren, see Regeerings Alamanak van Nederlandsch Indie 1857; for Rueb (born in Rotterdam 1814, died in Semarang 1877), see Nederland's Patriciaat 48 (1962), pp. 306-7.

60 Christiaans 1986, 2003. I am particularly grateful to Peter Christiaans (of the Indische Genealogische Vereniging in The Hague) for his invariably generously offered advice concerning the colonial communities in the mid-century Indies.

61 Opname suikerfabrieken 1857; for Fraser Eaton, Maclaine Watson, and A. MacNeill \& Co. as guarantors in a number of factories in Surabaya and the Oosthoek, see 'Staat der verschillende kultuur-inrigtingen onder ultimo December 1852; Suiker-kultuur', Exhibitum 17-3-1854/4, inv. 324, in: NA, Min. Kol. 1850-1900, nummer toegang 2.10.02.

62 'Register der overeenkomsten', inv. 4976, in: NA, NHM, nummer toegang 2.20.01.

63 '59e Jaarlijksch verslag van de Factorij te Batavia over het boekjaar 1884', p. 7, inv. 4552, in: NA, NHM, nummer toegang 2.20.01.
} 
Among other such investors possibly the best known - as a result of the need to untangle its myriad affairs in the wake of the crisis - was the Semarang firm of Dorrepaal, said to have 'relations' with some 22 sugar factories in the colony by 1884, and investments in agricultural ventures totalling around six million guilders. Another large investor was the Batavia firm of Dummler \& Co., thought in the same year to have bought $30 \%$ of the island's sugar crop. ${ }^{64}$

Both Dorrepaal and Dummler got into difficulties in 1884-1885 (the latter closed down completely and the former was radically transformed into an estate management company under new owners). The essential point about these mercantile investments, however, was the indication they give of the extent to which the Indies bourgeoisie as a whole had been involved in providing capital for the agricultural export sector of the colonial economy from the mid-century onward, and especially in the 1870s and early 1880s. This was particularly true in the case of sugar. One well-placed contemporary, the Koloniale Bank's Jan Hudig (1886:28), estimated in the wake of the crisis of the mid-1880s that a hundred million guilders had been invested in the colony's export agricultural sector in the decade or so prior to the crisis, and that as much as $75 \%$ of that money had come from within the Indies. He argued that the so-called sugar lords were not the profligate figures of popular legend; the 'greater part' of profit from sugar had been ploughed back into improvements to existing factories, into building new factories, and into new agricultural ventures outside the immediate range of the industry itself (Hudig 1886:16-23).

\section{Connections with the metropole}

Yet the Indies bourgeoisie were not alone in making such investments, and it would be a mistake to view their investments in isolation from those of their metropolitan counterparts. Indeed, it had long been the case that Dutch metropolitan commercial and financial networks had worked together with the colonial bourgeoisie. Back in the 1850s, for instance, several of the Java firms that acted as guarantors for sugar contracts were closely connected to commodity traders in the Netherlands. The well-known Rotterdam firm of Van Hoboken and the Amsterdam firm of Van Eeghen were cases in point. From the early 1860s (following, more than coincidentally, in the wake of the commercial crisis in Java discussed earlier), the connections became more institutionalized as financial capital joined mercantile capital in setting up the Nederlandsch-Indische Handelsbank (Netherlands Indies Trading

64 '59e Jaarlijksch verslag van de Factorij te Batavia over het boekjaar 1884', p. 7, inv. 4552, in: NA, NHM, nummer toegang 2.20.01; Schor, 'Gedenkboek Koloniale Bank', pp. 94-6, circa 1945, inv. 883, in: NA, Koloniale Bank, nummer toegang 2.20.04. 
Bank) and the Internationale Crediet- en Handelsvereeniging 'Rotterdam' (International Credit and Commerce Association 'Rotterdam'), better known as Internatio. ${ }^{65}$ In consequence, there were increasing inflows of metropolitan capital into Java sugar during the 1870s and early 1880s, well ahead of the sugar crisis of 1884 that has often been seen as the critical date for the onset of such investment. As Hudig has argued, however, the extent of this metropolitan investment should not be overestimated. Nor was 1870-1871 the watershed that has sometimes been assumed (Fasseur 1991).

Internatio, one of the original metropolitan investors from a decade earlier, appears to have burnt its fingers as a direct investor in sugar factories in the 1870s, and subsequently confined itself to providing working capital/ consignment contracts (the amount of sugar involved in such contracts was fairly inconsiderable: as late as 1883 it amounted to 12,300 tons, less than $4 \%$ of Java's total output). ${ }^{66}$ The Handelsbank had a significant enough portfolio of sugar and other agricultural investments by the time of the 1884 crisis for it to come within a hair's breadth of disaster (Van den Berg 1907:212-4; Korthals Altes 2004:99-143) but, like Internatio, it had held back from any major investment in the building of new factories or the renovation of old ones. It had 'relations' with some thirty factories, and nearly thirteen million guilders invested in cultuurrelaties in general, though these consisted (so it would appear) of working capital/consignment contracts. ${ }^{67}$ Certainly, on the capital investment front, only the Koloniale Bank and the NHM were more ambitious - the latter considerably so. In the early 1880s, the NHM Factorij owned, or largely controlled, a string of sugar factories along Java's north coast. ${ }^{6}$ The total value of such capital investments (by that date the firm had reduced its involvement in purely consignment contracts) amounted to something in excess of three million guilders. ${ }^{69}$ The newly arrived Koloniale

65 Van den Berg 1907:115. On the Handelsbank in particular, see Korthals Altes 2004.

66 The information relating to Internatio's investments in sugar in the years prior to 1885 comes from Jaarverslagen Internatio, 1863-1887, Gemeente Archief Rotterdam, Archief Internationale Crediet- en Handelsvereeniging 'Rotterdam' (Internatio), inv. 76. I am grateful to Jasper van de Kerkhof for kindly supplying me with this information.

67 Schor, 'Gedenkboek Koloniale Bank', pp. 91-4, circa 1945, inv. 883, in: NA, Koloniale Bank, nummer toegang 2.20.04; 'Verslag van de Raad van Commissarissen', 1865-1884', inv. 190, in: NA, Archief Nederlandsch-Indische Handelsbank 1863-1950, nummer toegang 2.20.03. Van den Berg 1907:203-5.

68 That is to say, the Factorij directly owned some factories, such as sugar factory Wonopringo (Pekalongan) and sugar factory Kemantran (Tegal), whereas in the case of others such as sugar factory Kalimatie (Pekalongan) the owners were so deeply in debt to the Factorij that the latter exercised de facto control over them.

69 Calculated on the basis of information about the book value of its own sugar factories $(950,000$ guilders) and loans to other manufacturers in '57e Jaarlijksch verslag van de Factorij te Batavia over het boekjaar 1882', pp. 55-8, inv. 4552; '59e Jaarlijksch verslag van de Factorij te Batavia over het boekjaar $1884^{\prime}$, p. 71, inv. 4552, in: NA, NHM, nummer toegang 2.20.01. Given the somewhat 
Bank (established 1881), meanwhile, had become involved in financing five new factories and in working on exclusive capital/consignment arrangements with four more. Its total investment in sugar by 1884 amounted to the better part of six million guilders. ${ }^{70}$

It is an essential point that little or none of this investment took place without the active participation of the Indies bourgeoisie. Ultimately, debate as to the relative capital inputs of the colonial bourgeoisie and their metropolitan counterparts is only partially relevant. The two groups were intimately linked, ${ }^{71}$ as the career of Jan Hudig demonstrates. Born in the Netherlands in 1840, a scion of an established Rotterdam merchant family, as a sixteen-yearold he served an apprenticeship in Van Hoboken's dockyard in Rotterdam and spent three years in England before arriving in Batavia in 1864. His acquaintances there included the young N.P. van den Berg, agent of the newly established Handelsbank (and later its president); the president of the Javasche Bank, Wiggers van Kerchem; and the head of the firm of Reijnst \& Vinju, A. van Delden. Hudig himself was employed in various agricultural ventures, mostly coffee, and lived with an Indies-Chinese woman, Tjan Joe. Revisiting Holland in 1874, he married a Dutch woman, M.H. van der Waarden, and returned to Java the following year. In 1878 he was again in Holland, where he took a position as secretaris of the NHM in Amsterdam. Resigning the following year, he travelled once again to the Indies, where he resided for a time as a guest of J.Th. Cremer - who was then well on his way to making the fortune as a tobacco planter that was to carry him into the upper echelons of the Dutch business and political world. In 1880 sickness forced Hudig back to Holland, where in the following year he founded the Koloniale Bank. ${ }^{72}$

\section{Conclusion: Indies bourgeoisie and the capitalist world economy}

From the early 1860s onward a situation was developing in Java in which both metropolitan and colonial bourgeois capital came together to finance the ongoing development of the sugar industry. The Cultuurstelsel, far from suppressing the growth of mercantile capital in the colony, created rich

\footnotetext{
fragmentary nature of the evidence, it may be that this figure (of capital sugar investments only) somewhat understates the Factorij's total commitment.

70 The exact sum was 5,712,000 guilders (with another 1,621,000 invested in coffee plantations). See Schor, 'Gedenkboek Koloniale Bank', pp. 18, 73, circa 1945, inv. 883, in: NA, Koloniale Bank, nummer toegang 2.20.04.

71 For evidence of the substantial overlap between the 'colonial' and 'metropolitan' bourgeoisie of the era, see Claver 2006:31-49, 67-90; Korthals Altes 2004:53-63, 89-98; Van Zwet 2004:51-216; Van den Berg 1913. For an authoritative anatomy of colonial-metropolitan business circles in subsequent decades, and especially during the inter-war period, see Taselaar 1998.

72 Schor, 'Gedenkboek Koloniale Bank', pp. 1-11, circa 1945, inv. 883, in: NA, Koloniale Bank, nummer toegang 2.20.04. Nederland's Patriciaat, 50 (1964), p. 260. For an extensive account of Hudig's career, see Claver 2006:105-9.
} 
opportunities for it. The trade in sugar, increasingly in 'private' hands from 1850 onward, appears to have constituted the largest source of such capital accumulation, though other export commodities also played a role, as did a parallel growth in imports.

An equally critical point, however, is that the emergence of a mid-century Indies bourgeoisie, either directly involved in the manufacture of sugar or in the international sugar trade (the two categories were apt to be blurred, as the foregoing discussion has shown), meant that support for the industrial project in Java sugar was intimately linked to the 'colonial' bourgeoisie's longstanding interface with its 'metropolitan' counterpart. A crucial consequence of this association was that when the Java sugar industry was hit by a worldwide and dramatic fall in sugar prices in the mid-1880s, its predominantly Indies bourgeois owners had already equipped it in line with international best practice. Increasingly refinanced thereafter from metropolitan sources, the industry was hence able to weather the crisis rather than succumb to it.

A glance at what happened - or rather, did not happen - in the notionally comparable sugar colonies of Mauritius and the Philippines in the late nineteenth century confirms the point. Both were seemingly well placed at midcentury to undergo similar development to that which occurred in Java after 1850. Indeed, Mauritius around 1850 had the more technologically advanced industry, and in the Philippines the quality of the raw material, particularly in Negros, was legendary. While they did not possess Java's apparent labour bonanza (actually a more problematic phenomenon than is often realized), neither Mauritius, with extensive supplies of indentured labour from India, nor Negros, with labour readily available from adjacent islands, were exactly labour starved - and both enjoyed an abundance of land.

Missing from the equation, on the other hand, was capital. Mauritius manufacturers lacked the intimate contacts with bourgeois capital in the British metropolis that characterized their Indies-Dutch counterparts in Java, and Indian capitalists seemed to have been unwilling to fill in the gap (Allen 1999:22-3). In the Philippines, an initial flush of British (and North American) mercantile capital in the 1860s dried up thereafter. Contemporary analysis of the Philippines industry late in the nineteenth century depicts it as capital starved. ${ }^{73}$

Java's 'sugar bourgeoisie', by contrast, were never cut off from metropolitan financing, and during the mid-century they were able to draw on both locally accumulated and metropolitan capital to finance an ongoing project of industrialized manufacture. The subvention from Holland of sugar manufacture in Java hence long preceded, and in crucial respects laid the ground-

73 In 1890s the Negros industry's foremost apologist lamented that a system of industrialized factories had yet to appear, arguing that it was 'because of his lack of capital' that the plantermanufacturer of Negros was forced to adopt 'quick and simple methods'. See Echaúz 1968:61. 
work for, the large-scale metropolitan refinancing of the Java sugar industry that took place after 1884. By the same token, however, that refinancing built on the foundations laid by the Indies bourgeoisie, which, in consequence, was integral to it rather than swept away by it.

Writing a few years ago about the sugar industry of nineteenth-century Mauritius, Richard B. Allen remarked on 'attempts to distinguish plantations from other large-scale agricultural units [...] by emphasizing the dependence upon metropolitan capital as a defining criteria of these systems'. He called attention to the 'need to look more closely at the dynamics of capital formation in colonial sugar economies', and, in particular, to the need for a critical reappraisal of the idea that the social and economic history of 'plantation colonies' is invariably to be 'described and analysed in terms of metropolitan capital's penetration into the colonial world, and the attendant consequences of incorporation into the modern capitalist world economy' (Allen 1999:2-3).

Mid-nineteenth-century Java offers further evidence for a critique of this orthodoxy of largely unproblematic metropolitan capital penetration. Indeed, if the foregoing account is at all correct, any emphasis on metropolitan capital as the prime or exclusive mover in the making of the colonial economy is in need of serious revision. As I have emphasized, however, such a revision does not run along the lines of asserting the primacy of bourgeois capital formation within the colony itself (and to that extent diverges from Allen's argument). Rather, it is based on a critique of the binary 'colony/metropolis', and on the argument that in the vital matter of capital formation within the sugar industry, an altogether more sensible formula is possible. Such a formula posits a long-standing and organic link between the bourgeoisie of both colony and metropole - and implies the need for a changed perspective on late nineteenth-century developments in the Indies in so far as the sugar industry is concerned.

More specifically, one critical consequence of demonstrating the existence of a nascent 'Indies' bourgeoisie within the bowels of the Cultuurstelsel is to dispose of the idea that toward the end of the nineteenth century 'new' Dutch imperialist capital took over a moribund state enterprise and became the prime influence over colonial development. Equally essential to that argument, however, is the proposition that Java's mid-century sugar bourgeoisie (of the 1850s to the 1880s) had always had a Janus-faced character: had always been both colonial and metropolitan to an extent that substantially prefigured late nineteenth-century developments while simultaneously modifying the orthodox view of the latter's epoch-making character. 


\section{References}

\section{Unpublished sources}

Bodleian Library, Oxford

Letter Books of John Palmer

Nationaal Archief, The Hague

Archief Cultuur-, Handel- en Industriebank 'Koloniale Bank/Cultuurbank NV' 18811969, nummer toegang 2.20.04

Archief Ministerie van Koloniën 1814-1849, nummer toegang 2.10.01

Archief Ministerie van Koloniën 1850-1900, nummer toegang 2.10.02

Archief Nederlandsche Handel-Maatschappij 1824-1964, nummer toegang 2.20.01

Collectie J.C. Baud, nummer toegang 2.21.007.58

Collectie G.K. van Hogendorp, nummer toegang 2.21.006.49

Universiteitsbibliotheek, Leiden

Collectie Nahuys

\section{Published sources}

Aguilar Jr, Filomeno V.

$1998 \quad$ Clash of spirits; The history of power and sugar planter hegemony on a Visayan island. Honolulu: University of Hawai'i Press.

Allen, Richard B.

1999 Slaves, freedmen, and indentured laborers in colonial Mauritius. Cambridge: Cambridge University Press. [African Studies Series 99.]

Anderson, Benedict R.O'G.

1983 'Old state, new society; Indonesia's New Order in comparative historical perspective', Journal of Asian Studies 42:477-96.

Baud, W.A.

1983 De semi-officiële en particuliere briefwisseling tussen J.C. Baud en J.J. Rochussen, 1845-1851; En enige daarop betrekking hebbende andere stukken. Assen: Van Gorcum. [Historische Bibliotheek 100.] Three vols.

Benda, J.

1966 'The pattern of administrative reforms in the closing years of Dutch rule in Indonesia', Journal of Asian Studies 25:589-605.

Berg, N.P. van den

1907 Munt-, crediet- en bankwezen, handel en scheepvaart in Nederlandsch-Indië; Historisch-statistische bijdragen. 's-Gravenhage: Nijhoff.

1913 'Uit de tijd van de oprichting en de eerste jaren van het bestaan der Nederlandsch-Indische Handelsbank', Indische Gids 35-2:987-1003.

Bergad, Laird W.

$1990 \quad$ Cuban rural society in the nineteenth century; The social and economic history of monoculture in Matanzas. Princeton, N.J.: Princeton University Press. 
Billig, Michael S.

1994 'The death and rebirth of entrepreneurism on Negros Island, Philippines; A critique of cultural theories of enterprise', Journal of Economic Studies 28-3:659-78.

Bosma, Ulbe

2005

'Het Cultuurstelsel en zijn buitenlandse ondernemers; Java tussen oud en nieuw kolonialisme', Tijdschrift voor Sociale en Economische Geschiedenis 2-2:3-28.

2007 'Sugar and dynasty in Yogyakarta', in: Ulbe Bosma, Juan Giusti and G. Roger Knight (eds), Sugarlandia revisited; Sugar and colonialism in Asia and the Americas, 1800-1940. London/New York: Berghahn.

Bosma, Ulbe and Remco Raben

2003 De oude Indische wereld, 1500-1920. Amsterdam: Bert Bakker. [De Geschiedenis van Indische Nederlanders.]

Christiaans, P.A.

1986 'Vincent (Van der Parra Breton)', De Indische Navorscher 2:50.

2003 'Van Beusechem', De Indische Navorscher 16:1-7.

Claver, Alex

2006 Commerce and capital in colonial Java; Trade finance and commercial relations between Europeans and Chinese, 1820s-1942. PhD thesis, Vrije Universiteit, Amsterdam.

Creutzberg, P.

1975

Changing economy of Indonesia; A selection of statistical source material from the early 19th century up to 1940; Vol. 1: Indonesia's export crops 1816-1940. The Hague: Nijhoff.

Deerr, Noel

1949-50 The history of sugar. London: Chapman and Hall. Two vols.

Doel, H.W. van den

1994 De stille macht; Het Europese binnenlands bestuur op Java en Madoera, 18081942. Amsterdam: Bert Bakker.

Elson, Robert Edward

1979 Sugar and peasants; The social impact of the western sugar industry on the peasantry of the Pasuruan area, East Java, from the Cultivation System to the Great Depression. PhD thesis, Monash University, Clayton.

1994 Village Java under the Cultivation System, 1830-1870. Sydney: Allen and Unwin. [Southeast Asia Publication Series 25.]

Enk, Elly Marie Corrie van

1999 Britse kooplieden en de cultures op Java; Harvey Thompson (1790-1837), en zijn financiers. PhD thesis, Vrije Universiteit, Amsterdam:

Echaúz, Robustiano

1978 Sketches of the island of Negros. Translated and annotated by Donn V. Hart; with an historical introduction by John A. Larkin. Athens, Ohio: Center for International Studies. [Papers in International Studies, Southeast Asia Series 50.] [Orignially published as Apuntes de la isla de Negros. Manila: Tipo-Litografía de Chofré, 1894.] 
Fasseur, Cees

1991

'Purse or principle; Dutch colonial policy in the 1860s and the decline of the Cultivation System', Modern Asian Studies 25-1:33-52.

1992 The politics of colonial exploitation; Java, the Dutch, and the Cultivation System. Ithaca, N.Y.: Southeast Asia Program, Cornell University. [Studies on Southeast Asia.]

1996 Indischgasten. Amsterdam: Bert Bakker.

1994 De Indologen; Ambtenaren voor de Oost, 1825-1950. Tweede herziene druk. Amsterdam: Bert Bakker. [First editon 1993.]

Furnivall, J.S.

1939 Netherlands India; A study of plural economy. With an introduction by

A.C.D. de Graeff. Cambridge: Cambridge University Press.

Gevers Deynoot, W.T.

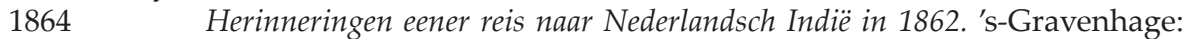
Nijhoff.

Gorkom, K.W. van

1879 'Historische schets van de suikerindustrie op Java', Tijdschrift voor Nijverheid en Landbouw in Nederlandsch-Indie 23:229-97.

Houben, Vincent J.H.

1993 'Private estates in Java in the nineteenth century; A reappraisal', in: J. Thomas Lindblad (ed.), New challenges in the modern economic history of Indonesia; Proceedings of the first Conference on Indonesia's Modern Economic History, Jakarta, October 1-4, 1991, pp. 47-66. Leiden: Programme of Indonesian Studies.

1994 Kraton and Kumpeni; Surakarta and Yogyakarta, 1830-1870. Leiden: KITLV Press. [Verhandelingen 164.]

Hudig Dz, Jan

$1886 \quad$ Suikerlords. Amsterdam: Van Kampen.

Junghuhn, F.

1851 Terugreis van Java naar Europa met de zoogenaamde Engelsche overlandpost, in de maanden September en October, 1848. Zalt-Bommel: Noman.

Knight, Franklin W.

1977 'Origins of wealth and the sugar revolution in Cuba, 1750-1850', The Hispanic American Historical Review 57-2:231-53.

Knight, G.R.

1980

'From plantation to padi-field; The origins of the nineteenth-century transformation of Java's sugar industry', Modern Asian Studies 14-2:177204.

Koloniaal verslag

1868-1924 Koloniaal verslag. 's-Gravenhage: Algemeene Landsdrukkerij. [Bijlage $C$ van het verslag der handelingen van de Tweede Kamer der StatenGeneraal.]

Korthals Altes, W.L.

$1991 \quad$ Changing economy in Indonesia; A selection of statistical source material from the early 19th century up to 1940; Vol. 12a: General trade statistics 18221940. Amsterdam: Royal Tropical Institute (KIT). 
Tussen cultures en kredieten; Een institutionele geschiedenis van de Nederlandsch-Indische Handelsbank en Nationale Handelsbank, 1863-1964. Amsterdam: Nederlands Instituut voor het Bank-, Verzekerings- en Effectenbedrijf. [NIBE-Bankhistorische Reeks 24.]

Krajenbrink, J.A.

1866 De zaken van het land Simbang nader toegelicht. 's-Gravenhage: Nijhoff. [Uitgegeven door de Commissie van Liquidatie des Boedels van wijlen den Heer J.E. Herderschee.]

Larkin, John A.

$1993 \quad$ Sugar and the origins of modern Philippine society. Berkeley/Los Angeles: University of California Press.

Leidelmeijer, Margaret

1997 Van suikermolen tot grootbedriff; Technische vernieuwing in de Java-suikerindustrie in de negentiende eeuw. PhD thesis, Technische Universiteit Eindhoven.

Lock, Charles G. Warnford, G.W. Wigner and R.H. Harland

$1882 \quad$ Sugar growing and refining; A comprehensive treatise on the culture of sugaryielding plants, and the manufacture, refining, and analysis of cane, beet, maple, melon, milk, palm, sorghum, and starch sugars: With copious statistics of their production and commerce, and a chapter on the distillation of rum. McCoy, Alfred W. London/New York: Spon.

$1982 \quad$ 'A queen dies slowly; The rise and decline of Iloilo City', in: Alfred W. McCoy and Ed. C. de Jesus, Philippine social history; Global trade and local transformations, pp. 297-358. Quezon City: Ateneo de Manila University Press, Sydney: Allen and Unwin. [Southeast Asia Publications Series 7.]

McVey, Ruth

1992 'The materialization of the Southeast Asian entrepreneur', in: Ruth McVey (ed.), Southeast Asian capitalists, pp. 8-33. Ithaca, N.Y.: Southeast Asia Program, Cornell University. [Studies on Southeast Asia 9.]

Mansvelt, W.M.F.

[1924] Geschiedenis der Nederlandsche Handel-Maatschappij. Haarlem: Enschedé. Two vols.

Memorie suiker-industrie

1865 Memorie over de suiker-industrie in de Gouvernements residentiën van Midden-Java, door de Kamer van Koophandel en Nijverheid te Samarang ingediend aan Z.E. den Gouverneur-Generaal van Ned. Indië. Samarang: Van Dorp.

Millard, J.

1869 De suikerindustrie op Java. 's-Gravenhage: Nijhoff.

Nahuys van Burgst, H.G.

1852 Herinneringen uit het openbare en bijzondere leven (1799-1849) van Mr. H.G. baron Nahuys van Burgst. Utrecht: Van de Weijer.

Neve, R.G. de and D. van Duijn

1994 'De oprichters van de loge "De Ster in het Oosten" te Batavia', De Indische Navorscher 7:194-220. 
Netscher, F.H.J.

$1864 \quad$ Regt en onregt of de toestand der gewestelijke besturen in Indië tegenover de particuliere industrie. 's-Gravenhage: Susan.

Onghokham

1978 'The inscrutable and the paranoid; An investigation into the sources of the Brotodiningrat affair', in: Ruth T. McVey (ed.), Southeast Asian transitions; Approaches through social history. With the assistance of Adrienne Suddard, pp. 112-57. New Haven, Conn.: Yale University Press. [Yale Southeast Asia Studies 8.] [Essays written to honor the late Harry J. Benda.]

Oostindie, Gert J.

1984 'La burguesia Cubana y sus caminos de hierro, 1830-1868', Boletin de Estudios Latinoamericanos y del Caribe 37:99-115.

Opname suikerfabrieken Java

[1857] Stukken betreffende het onderzoek der (bij besluit van den Gouverneur-Generaal van Nederlandsch Indië van 8 December 1853, no. 10) benoemde commissie voor de opname der verschillende suikerfabrieken op Java. [Batavia]: Commissie voor de opname der verschillende suikerfabrieken op Java.

Pasleau, Suzy 1992

John Cockerill; Itinéraire d'un géant industriel. Alleur (Liège): Éditions du Perron.

Reinsma, R.

$1955 \quad H e t$ verval van het Cultuurstelsel. Den Haag: Van Keulen.

Rogge, Jan

1949 Het handelshuis Van Eeghen; Proeve eener geschiedenis van een Amsterdamsch handelshuis. Amsterdam: Van Ditmar.

Rush, James R.

1990 Opium to Java; Revenue farming and Chinese enterprise in colonial Indonesia, 1860-1910. Ithaca, N.Y./London: Cornell University Press.

Salmon, Claudine

1991 'The Han Family of East Java; Entrepreneurship and politics (18th-19th centuries)', Archipel 41-53-88.

Soames, Peter

$1872 \quad$ A treatise on the manufacture of sugar from sugar cane. London/New York: Spon.

Sutherland, Heather

1979 The making of a bureaucratic elite; The colonial transformation of the Javanese priyayi. Singapore: Heinemann.

Taselaar, Arjen

1998 De Nederlandse koloniale lobby; Ondernemers en de Indische politiek 19141940. Leiden: Research School CNWS, School of Asian, African, and Amerindian Studies. [CNWS Publications 62.]

Tjoa Tjwan Phing and J.J. Moolenaar

1957125 jaren Tjandi; Een historisch overzicht omtrent suiker, de Java suikerindustrie, de onderneming Tjandi. Surabaja: Fuhri. 
Van Niel, Robert

1964 'The Alfred A. Reed papers; And other materials pertaining to the East Indies in the state of Rhode Island, U.S.A.', Bijdragen tot de Taal-, Landen Volkenkunde 120:224-30.

1992 Java under the Cultivation System; Collected writings. Leiden: KITLV Press. [Verhandelingen 150.]

2005 Java's northeast coast, 1740-1840; A study in colonial encroachment and dominance. Leiden: CNWS. [CNWS Publications 137, Studies in Overseas History 6.]

Weiss, Linda

1996 'Sources of the East Asian advantage; An institutional analysis', in: Richard Robison (ed.), Pathways to Asia; The politics of engagement, pp. 171-201. St. Leonards, NSW: Allen and Unwin.

Westendorp Boerma, J.J. (ed.)

1956 Briefwisseling tusssen J. van den Bosch en J.C. Baud, 1829-1832 en 1834-1836. Utrecht: Kemink. [Werken uitgegeven door het Historisch Genootschap, Derde Serie, 80-81.] Two vols.

Wimmer, D.J. and A.M. Tempelaars

1997 Inventaris van het Archief van het Hoofdkantoor van de Nederlandsche Handel-Maatschapppij NV 1824-1964. The Hague: NA.

Wray, Leonard

1848 The practical sugar planter; A complete account of the cultivation and manufacture of the sugar-cane, according to the latest and most improved processes: Describing and comparing the different systems pursued in the East and West Indies and the Straits of Malacca, and the relative expenses and advantages attendant upon each: Being the result of sixteen years' experience as a sugar planter in those countries. London: Smith, Elder.

Zwet, Jan Rutger van

$2004 \quad$ President in Indië en Nederland; Mr. N.P. van den Berg als centraal bankier. $\mathrm{PhD}$ thesis, Leiden University. 

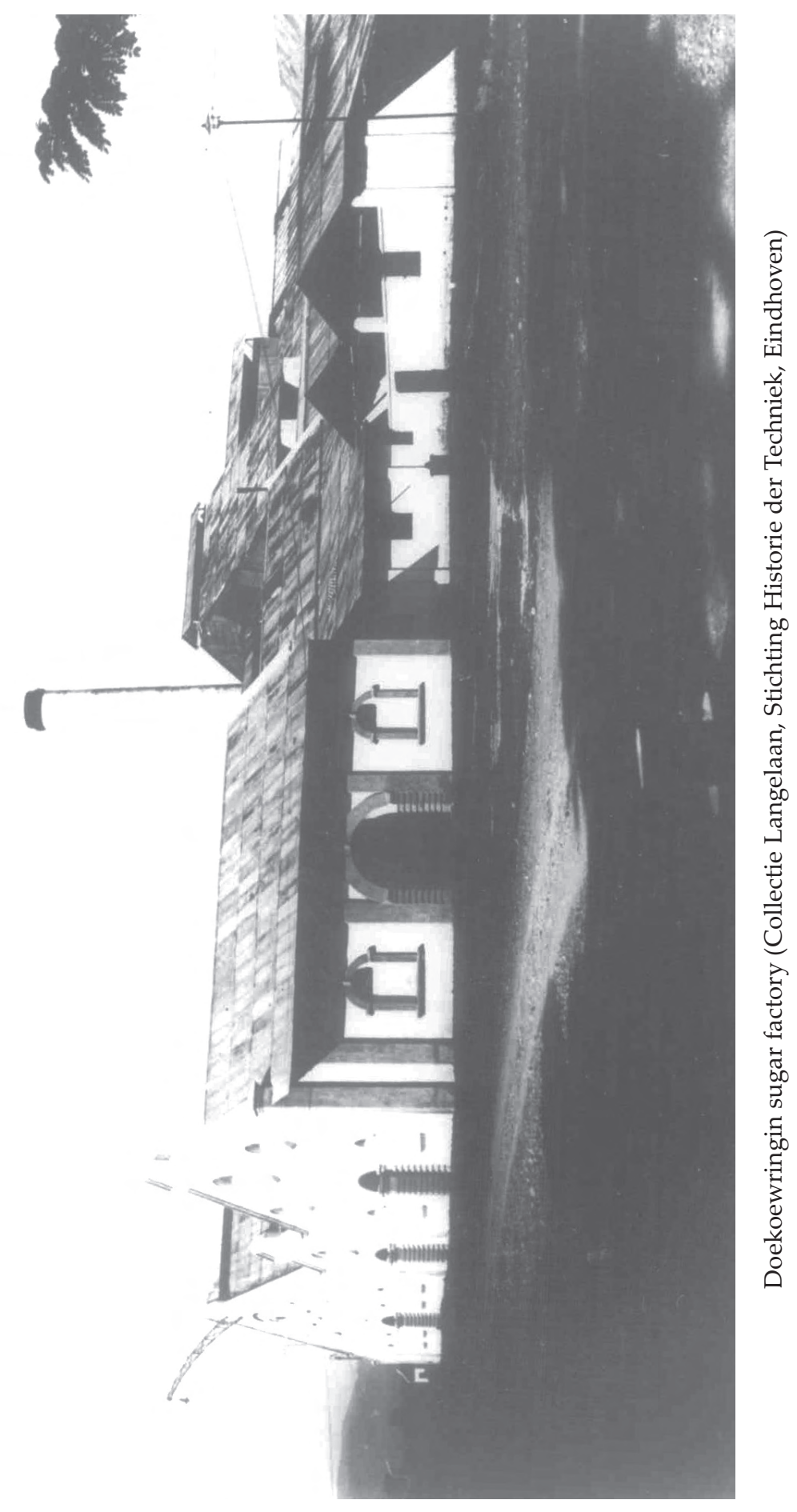


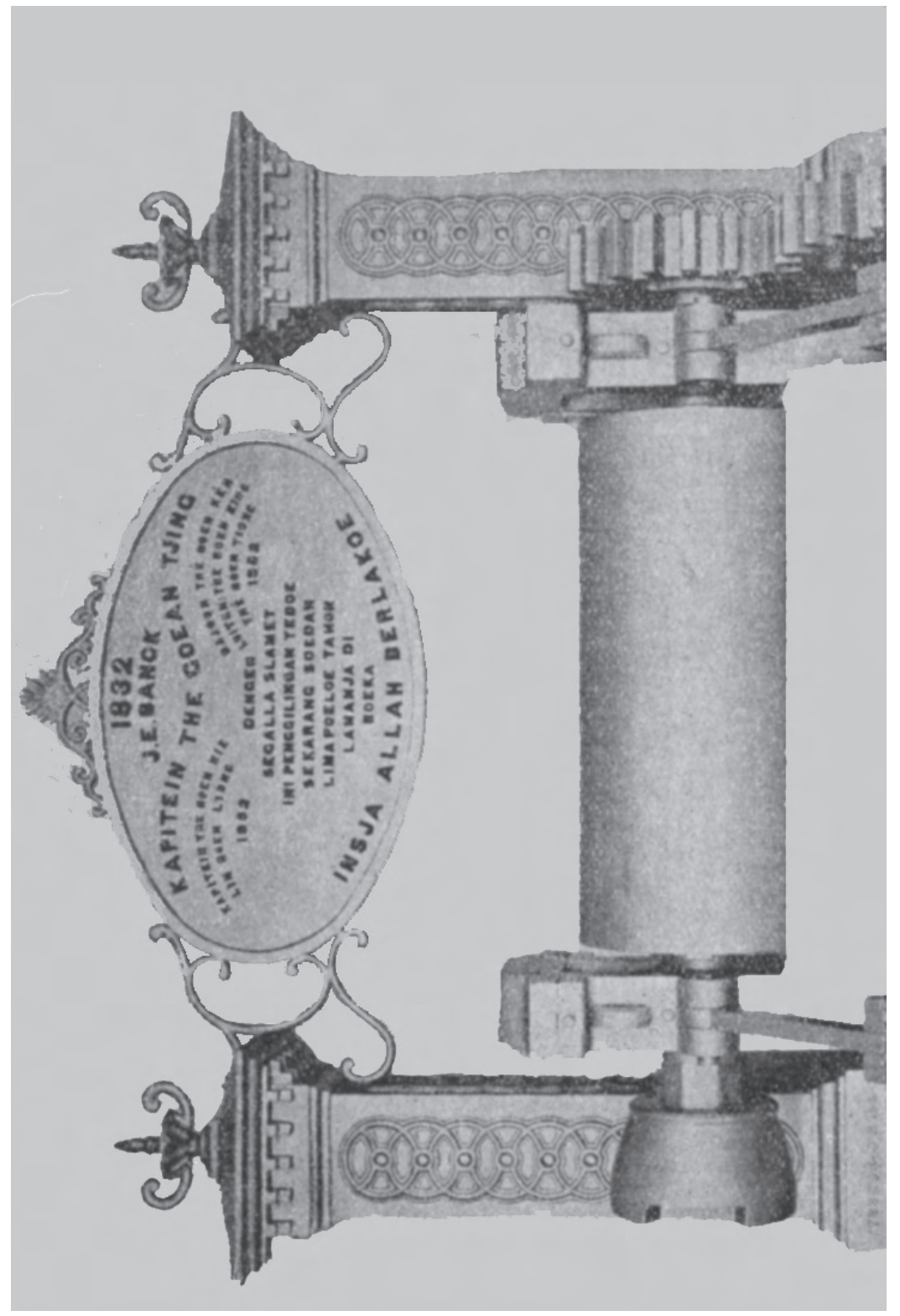

Е

조

䒕

๑

떵ㅇㅇㅇ

क

艺

है

¿ี

त

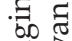

要

ฐ

岁㤩

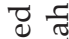

인

乩

क

ڤ્)

ฮี

约

드

3

$\begin{array}{ll}0 & 0 \\ 0 & 0 \\ 0 & \vdots\end{array}$

无

సี

$\rightarrow$ के

E

$\stackrel{\varpi}{\oplus} . \Xi$

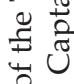

$=$

ฮี

के 


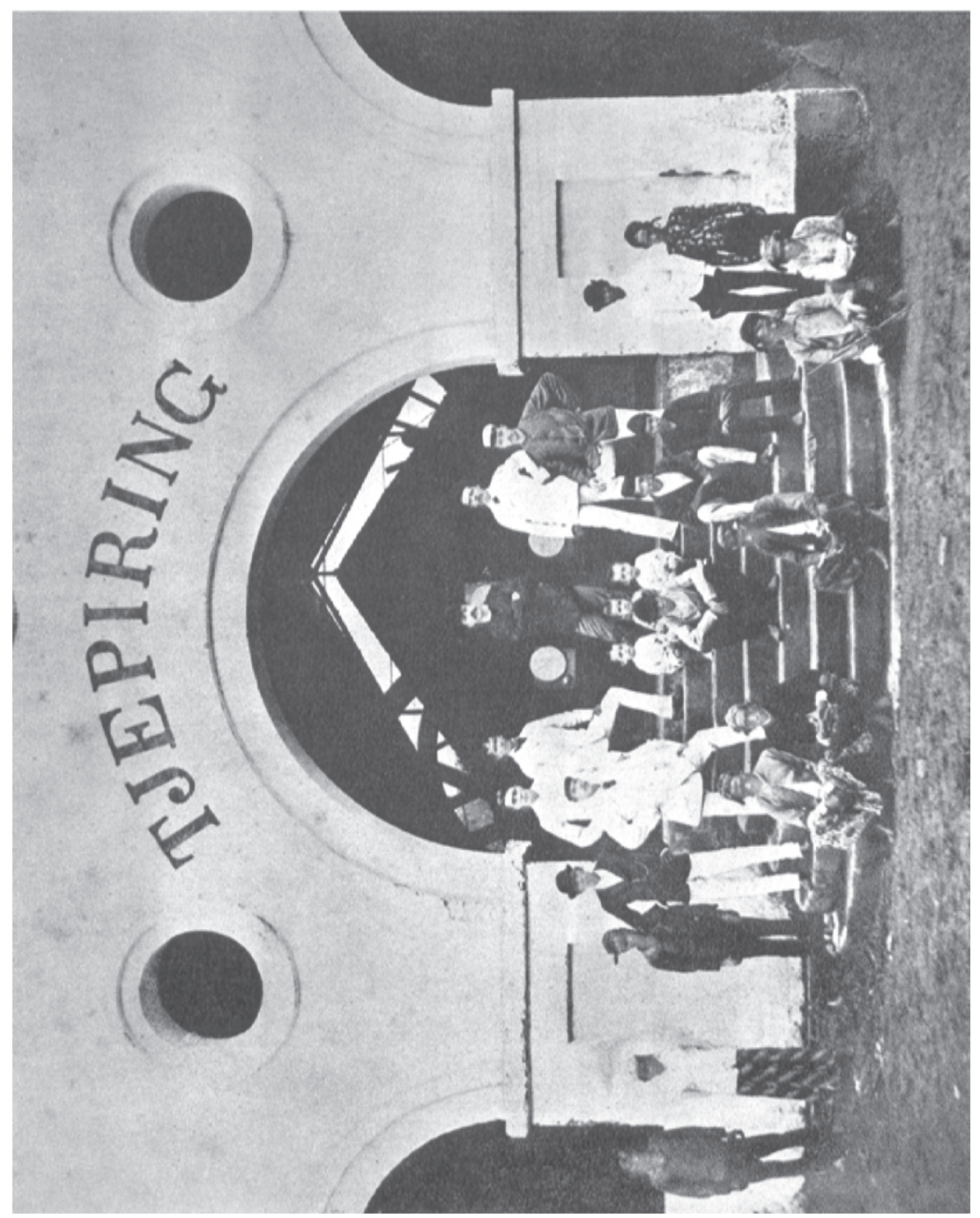

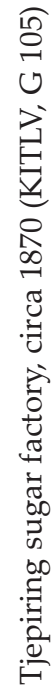




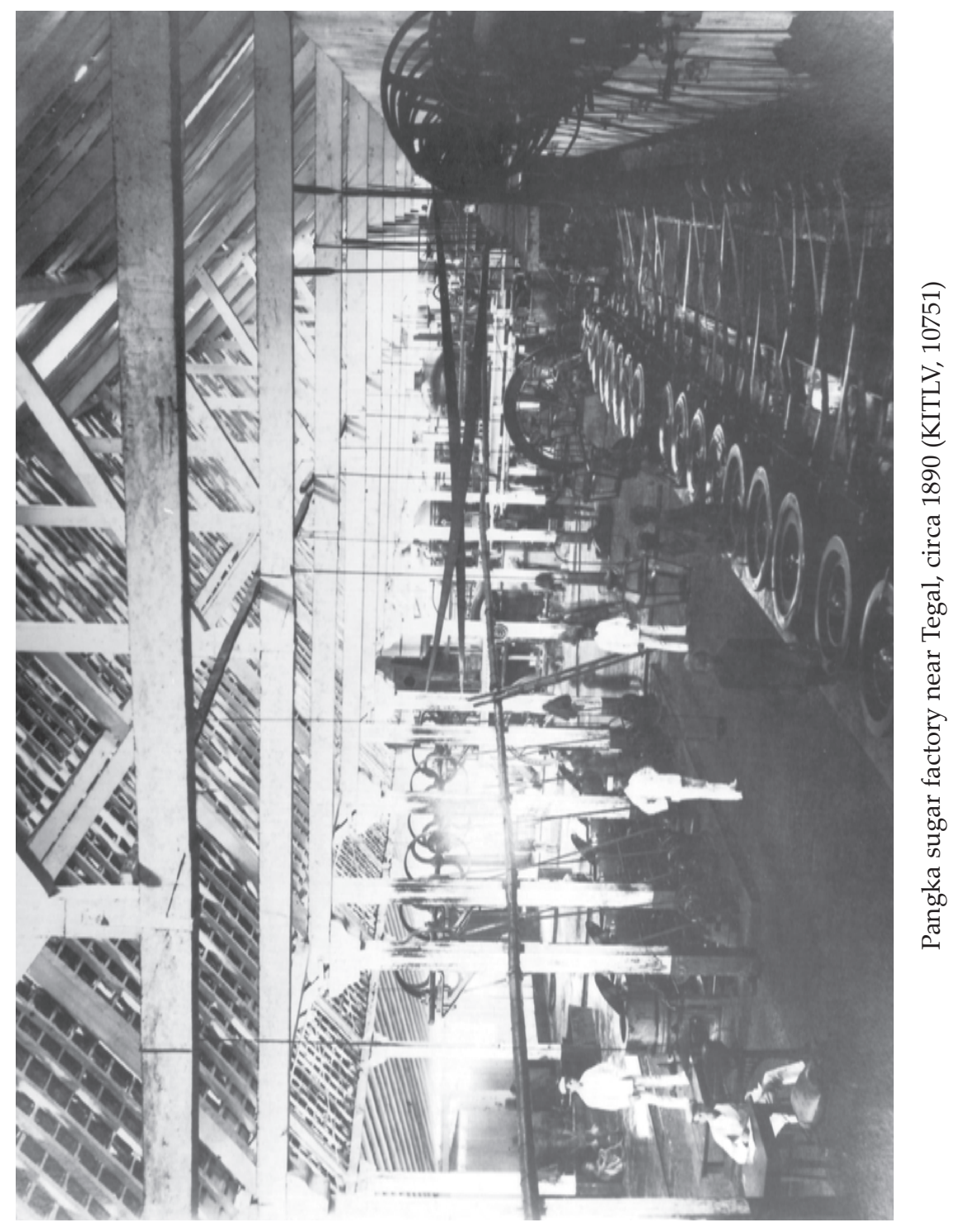

